This document was prepared in conjunction with work accomplished under Contract No. DE-AC09-96SR18500 with the U. S. Department of Energy.

\title{
DISCLAIMER
}

This report was prepared as an account of work sponsored by an agency of the United States Government. Neither the United States Government nor any agency thereof, nor any of their employees, nor any of their contractors, subcontractors or their employees, makes any warranty, express or implied, or assumes any legal liability or responsibility for the accuracy, completeness, or any third party's use or the results of such use of any information, apparatus, product, or process disclosed, or represents that its use would not infringe privately owned rights. Reference herein to any specific commercial product, process, or service by trade name, trademark, manufacturer, or otherwise, does not necessarily constitute or imply its endorsement, recommendation, or favoring by the United States Government or any agency thereof or its contractors or subcontractors. The views and opinions of authors expressed herein do not necessarily state or reflect those of the United States Government or any agency thereof. 


\section{TECHNICAL BASIS FOR ELIMINATING CARBON-14 AS A REPORTABLE RADIONUCLIDE IN DWPF GLASS}

N. E. Bibler

J. R. Fowler

December 2004

Immobilization Technology Section Savannah River National Laboratory Aiken, SC 29808

Prepared for the U.S. Department of Energy Under Contract Number DEAC09-96SR18500

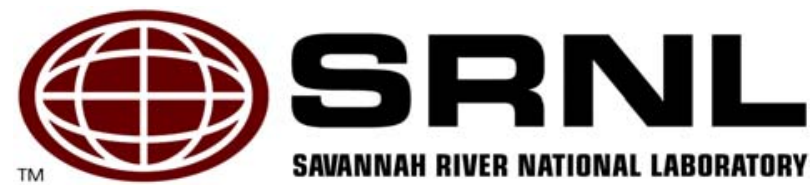


This page was intentionally left blank 
Key Words:

Carbon-14

WAPS Radionuclides

DWPF Glass

Retention:

Permanent

\title{
TECHNICAL BASIS FOR ELIMINATING CARBON-14 AS A REPORTABLE RADIONUCLIDE IN DWPF GLASS
}

\author{
N. E. Bibler \\ J. R. Fowler
}

December 2004

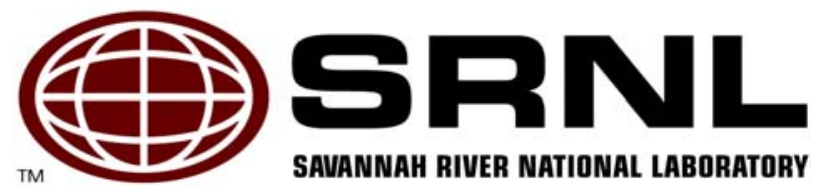


This page was intentionally left blank 


\section{EXECUTIVE SUMMARY}

The Defense Waste Process Facility (DWPF) of Savannah River Site (SRS) is immobilizing the High Level Waste (HLW) sludges at SRS into a borosilicate glass for geologic disposal in a repository. In order for the glass to be acceptable to the repository, a set of acceptance specifications have been written. These are published as the "Waste Acceptance Product Specifications (WAPS) for Vitrified High-Level Waste Forms." " Specification 1.2 of the WAPS requires that, "The Producer shall report the inventory of radionuclides (in Curies) that have half-lives longer than 10 years and that are, or will be, present in concentrations greater than 0.05 percent of the total inventory for each waste type indexed to the years 2015 and 3115”. As part of the strategy developed to meet Specification 1.2, the DWPF elected to report for each waste type, all radionuclides with half-lives greater than 10 years that have concentrations greater than 0.01 percent of the total inventory from time of production through the 1100 year period from 2015 through 3115. ${ }^{\text {b }}$ For the sludge batches processed thus far by the DWPF, either 26 or 27 radionuclides have been identified as reportable in the first three sludge batches. One of these radionuclides is carbon-14.

This report presents results of an investigation to determine if carbon and thus the carbon-14 would survive DWPF processing and be reportable in DWPF glass. Based on a thorough literature review, a review of process knowledge, and the expected chemistry of carbon in the DWPF process, we conclude all chemical forms of carbon in SRS HLW are converted to gaseous oxides during DWPF processing. Thus carbon-14 would not be a reportable component of the final HLW glass.

The principal form of the carbon in HLW, including both the sludge and the salt tanks, is the carbonate anion resulting from caustic dissolution of aluminum cladding of the SRS reactor fuels and targets. This anion is converted to carbon dioxide during acidic processing of the HLW in the DWPF Sludge Receipt Adjustment Tank and the Slurry Mix Evaporator. The carbon dioxide is vented to the atmosphere through the DWPF exhaust system. Other forms of carbon in the HLW such as formate and oxalate salts or degraded extractants and resins are oxidized in the DWPF melter to carbon dioxide or carbon monoxide. These gases are also vented to the atmosphere through the DWPF exhaust system. Based on this known chemistry during processing and immobilizing the waste to HLW glass, we conclude that the concentration of carbon-14 will be insignificant in the glass with regard to reporting for waste acceptance.

This report also presents results for the analysis of two samples of a DWPF glass taken from the pour stream of the DWPF melter during processing Sludge Batch 1B (SB1B). ${ }^{\mathrm{C}}$ Although carbon-14 had been measured in the SB1B and was found reportable, ${ }^{\mathrm{d}}$ it was not detected in the glass. Based on the minimum detection limits for carbon-14 in the analyses, greater than 94 to $98 \%$ of the carbon-14 was vented to the DWPF exhaust system and was not in the glass. As a result the carbon-14 no longer met the WAPS or the WCP requirement to be considered as a reportable radionuclide in SB1B.

On the basis of the above, we conclude that measuring carbon-14 in a batch of HLW going to the DWPF for processing is not necessary to determine if the carbon-14 is reportable based on Specification 1.2 of the WAPS or the specification in the WCP. Any carbon-14 that is in that batch of HLW will be vented to the DWPF exhaust system during DWPF processing.

\footnotetext{
${ }^{a}$ Office of Environmental Restoration and Waste Management, Waste Acceptance Product Specifications for Vitrified High-Level Waste Forms, USDOE DocumentDOE/EM-0093, Rev. 2, (12/96).

b Westinghouse Savannah River Company, “DWPF Waste Form Compliance Plan (U)”, WSRC-IM-91-116-0, Rev.5, (1995).

${ }^{\mathrm{c}}$ Bibler, N. E., and Fellinger, T. L., Results of Radionuclide Composition for DWPF Macro Batch 2 Glass Pour Stream Sample Taken During the Pouring of CanisterS01142, Rev.1, WSRC-2000-00418, Rev. 1 (2004).

${ }^{\mathrm{d}}$ Fellinger, T. L., Bibler, N. E., and Harbour, J., R., “Characterization of and Waste Acceptance Radionuclides to be Reported for DWPF Macro Batch 2 (ESP 215-ESP 221) Rev. 1”, WSRC-99-00436,Rev 1 (2004).
} 


\section{TABLE OF CONTENTS}

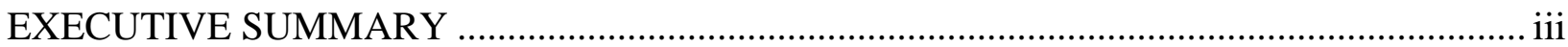

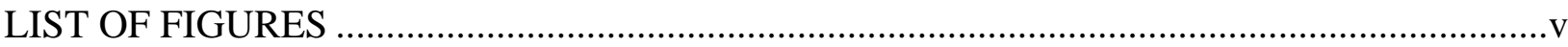

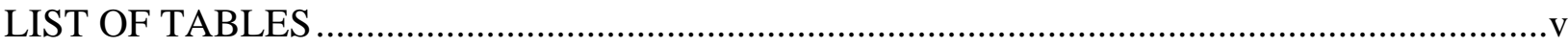

LIST OF ACRONYMS …………………...................................................................... vi

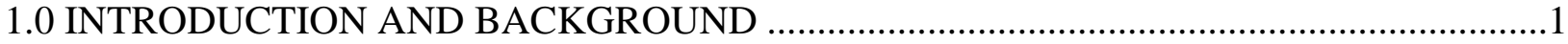

2.0 MEASURED CONCENTRATIONS OF CARBON-14 IN SAMPLES FROM SRS HLW

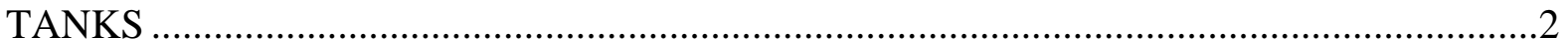

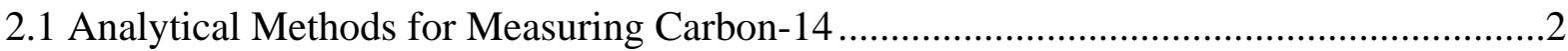

2.2 Measured Concentrations in Sludge and Salt HLW Slurries.................................................

3.0 PRODUCTION OF CARBON-14 IN THE REACTORS AT SRS ………………...................

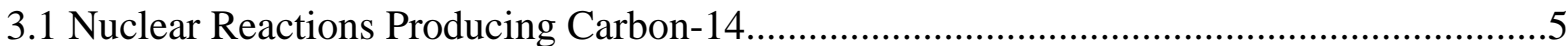

3.2 Possible Sources of Carbon-14 Precursors in SRS Reactors ..............................................6

3.3 Chemical Behavior of Carbon-14 Species During Dissolution of SRS Reactor Fuels and Targets ............................................................................................................6

4.0 MECHANISMS FOR LOSS OF CARBON-14 DURING DWPF PROCESSING ...................8

4.1 Losses During SRAT Processing...................................................................................

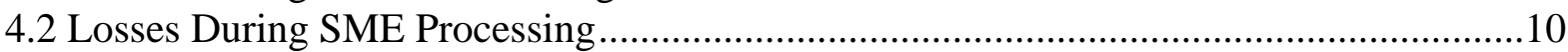

4.3 Carbon-14 Losses During the Melting Process ...................................................................11

4.3.1 Decomposition of Formate and Oxalate Salts ........................................................12

4.3.2 Decomposition of Mercuric Cyanide.......................................................................12

4.3.3 Decomposition of Carbonate and Bicarbonate Salts .................................................13

4.3.4 Decomposition of Elemental Carbon.........................................................................13

5.0 MEASUREMENT OF CARBON-14 IN SB1B GLASS .......................................................14

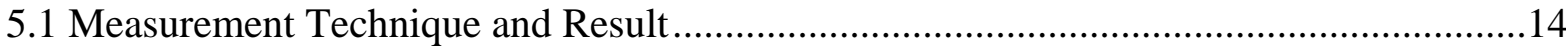

5.2 Calculation of the Waste Dilution Factor For SB1B …….................................................15

5.3 Prediction of Carbon-14 Concentration in Glass and the Fraction Lost in DWPF

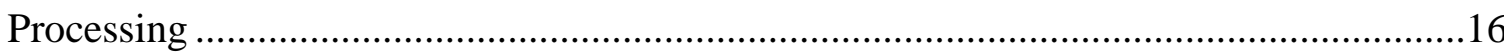

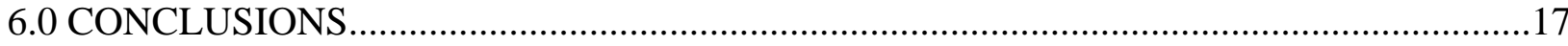

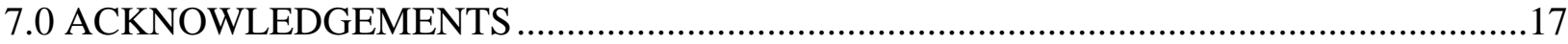

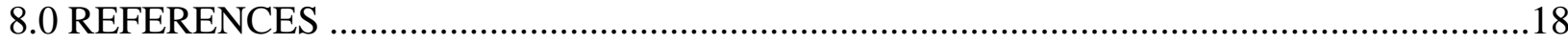

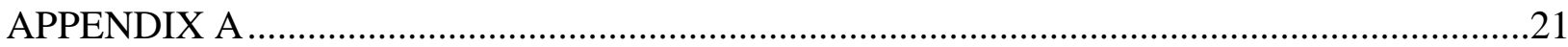




\section{LIST OF FIGURES}

Figure 4-1 Carbon Dioxide Evolution and pH Changes during the SRAT Process Performed in the SRNL Shielded Cells to Qualify SB2 for DWPF Processing...

Figure 4-2 Carbon Dioxide Evolution and $\mathrm{pH}$ Changes during the SME Process Performed in the SRNL Shielded Cells to Qualify SB2 for DWPF Processing...........................10

\section{LIST OF TABLES}

Table 2-1 Results of Measurements of Carbon-14 in SRS HLW Samples

Table 5-1 Results of Measurements of C-14 in Samples of SB1B Crushed Glass and Dried SB1B Slurry ............................................................................................... 15

Table 5-2 Concentrations (Wt\%) of Major Nonradioactive Elements Specific to the Waste in S01142 Glass Along With Concentrations Determined in the Dried Sludge Slurry and the Calculated Waste Dilution Factor (WDF). 


\section{LIST OF ACRONYMS}

$\begin{array}{ll}\text { ADS } & \text { Analytical Development Section } \\ \text { CRC } & \text { Cesium Removal Columns } \\ \text { DWPF } & \text { Defense Waste Processing Facility } \\ \text { DWPF-WSE } & \text { DWPF Waste Solidification Engineering } \\ \text { HM } & \text { H Modified Purex Process } \\ \text { HLW } & \text { High Level Waste } \\ \text { RBOF } & \text { Receiving Basin for Offsite Fuels } \\ \text { SB1A } & \text { Sludge Batch 1A } \\ \text { SB1B } & \text { Sludge Batch 1B } \\ \text { SB2 } & \text { Sludge Batch 2 } \\ \text { SME } & \text { Slurry Mix Evaporator } \\ \text { SRAT } & \text { Sludge Receipt and Adjustment Tank } \\ \text { SRNL } & \text { Savannah River National Laboratory } \\ \text { SRP } & \text { Savannah River Plant } \\ \text { SRS } & \text { Savannah River Site } \\ \text { TBP } & \text { Tributylphosphate } \\ \text { WAPS } & \text { Waste Acceptance Product Specifications } \\ \text { WCP } & \text { Waste Form Compliance Plan } \\ \end{array}$




\subsection{INTRODUCTION AND BACKGROUND}

The Defense Waste Process Facility (DWPF) of Savannah River Site (SRS) is currently immobilizing the High Level Waste (HLW) sludges at SRS into a borosilicate glass for disposal in a geologic repository. Specific acceptance specifications have been written for transfer of the canisters filled with HLW glass to the repository. These are published as the "Waste Acceptance Product Specifications (WAPS) for Vitrified High-Level Waste Forms.”[1] Specification 1.2 of the WAPS requires that, "The Producer shall report the inventory of radionuclides (in Curies) that have half-lives longer than 10 years and that are, or will be, present in concentrations greater than 0.05 percent of the total inventory for each waste type indexed to the years 2015 and 3115”. As part of the strategy developed to meet Specification 1.2, the DWPF will report for each waste type, all radionuclides (with half-lives greater than 10 years) that have concentrations greater than 0.01 percent of the total inventory from time of production through the 1100 year period from 2015 through 3115.[2] The initial listing of radionuclides to be included is based on the design-basis glass as identified in the Waste Form Compliance Plan (WCP) [2]. However, this list must be expanded if other radionuclides with half-lives greater than 10 years are identified that meet the greater than $0.01 \%$ criterion for Curie content. Based on analyses of the first three SRS sludge batches that were processed in the DWPF, either 26 or 27 radionuclides have been identified as reportable under Specification 1.2.[3-5] In Sludge Batch 1B (SB1B) and in Sludge Batch 2 (SB2) one of these radionuclides is Carbon-14 $\left({ }^{14} \mathrm{C}\right)$ with a half life of 5730 years.[6] When the first sludge batch was being prepared, Sludge Batch $1 \mathrm{~A}$ (SB1A), the ${ }^{14} \mathrm{C}$ concentration was very low and was projected to be lost in DWPF processing as was suggested by the work of Fowler and Coleman that had been published earlier.[7] Consequently, ${ }^{14} \mathrm{C}$ was not considered as a reportable radionuclide.[8] Based on measurements of ${ }^{14} \mathrm{C}$ in Sludge Batch $1 \mathrm{~B}$ and Sludge Batch 2, however, ${ }^{14} \mathrm{C}$ did become reportable. [4,5] It becomes reportable after the sludge is $\sim 300$ years old. In the year $3115{ }^{14} \mathrm{C}$ will comprise $\sim 0.046 \%$ of the Curie content of the waste and is thus reportable, based on the protocol used in the WCP. Both of these percentages are less than the $0.05 \%$ required by the WAPS but larger than the $0.01 \%$ in the WCP.

The purpose of this report is to provide a technical basis for removing ${ }^{14} \mathrm{C}$ as a reportable radionuclide. There are two parts to this technical basis. The first part is based on consideration of the chemistry of the carbon species in the DWPF processes. Indeed the chemistry of carbon suggests that most if not all of it would be vented to the exhaust system of the DWPF as $\mathrm{CO}_{2}$ or CO during SRAT and SME processing, with any residual carbon species being volatilized from the melter. The second part is based on measurements of ${ }^{14} \mathrm{C}$ in SB1B that was fed to the DWPF for immobilization and measurements of ${ }^{14} \mathrm{C}$ in a sample of glass from the melter pour stream during the processing of SB1B. Even though the radionuclide ${ }^{14} \mathrm{C}$ was detected in the sludge, it was not detected in the glass. These results further support the conclusion that all the carbon species are volatilized during DWPF processing.

This report first presents results of measurements of ${ }^{14} \mathrm{C}$ in HLW samples at SRS. These results indicate that ${ }^{14} \mathrm{C}$ is indeed a trace radionuclide in the HLW. To evaluate mechanisms for release of ${ }^{14} \mathrm{C}$ in the DWPF processes, the sources of the ${ }^{14} \mathrm{C}$ and its possible chemical forms in the HLW are discussed. The mechanisms for losses of carbon (which includes ${ }^{14} \mathrm{C}$ ) during DWPF processing are then discussed. Finally the results of attempts to measure ${ }^{14} \mathrm{C}$ in a DWPF glass containing SB1B are presented. 


\subsection{MEASURED CONCENTRATIONS OF CARBON-14 IN SAMPLES FROM SRS HLW TANKS}

In this section we briefly discuss the method for measuring the ${ }^{14} \mathrm{C}$ content of SRS HLW samples and then present results for both sludge and salt slurries.

\subsection{Analytical Methods for Measuring Carbon-14}

Because the concentrations of ${ }^{14} \mathrm{C}$ are low in the SRS HLW compared to the concentrations of other betaemitters such as ${ }^{90} \mathrm{Sr}$ and ${ }^{137} \mathrm{Cs}$, only methods that separate carbon from bulk samples are suitable to analyze ${ }^{14} \mathrm{C}$.[9] The methods of measuring ${ }^{14} \mathrm{C}$ in SRS HLW samples are based on the conversion of carbon species into gaseous $\mathrm{CO}_{2}$ by treating with strong acid. The evolved $\mathrm{CO}_{2}$ is trapped as carbonate in a caustic solution. Aliquots of this solution are then counted by liquid scintillation techniques for the ${ }^{14} \mathrm{C}$ beta particles. The characteristic ${ }^{14} \mathrm{C}$ beta particles have an average energy of $0.0495 \mathrm{MeV}$ and a maximum energy of $0.156 \mathrm{MeV}$. Usually triplicate samples of the dried sludge or salt were dissolved to liberate the $\mathrm{CO}_{2}$. This method requires the use of a standard ${ }^{14} \mathrm{C}$ sample such as carbonate that contains a known amount of ${ }^{14} \mathrm{C}$ to determine the efficiency of the method for collecting the $\mathrm{CO}_{2}$. The results for the samples are then corrected for this efficiency.

The first method used at SRS was based on treating samples of dried waste with sulfuric acid.[7] The acid reacted with all the carbonates in the radioactive sample to produce gaseous $\mathrm{CO}_{2}$. Using a nitrogen purge the $\mathrm{CO}_{2}$ was passed though a caustic solution where the $\mathrm{CO}_{2}$ dissolved to form carbonates in the solution. This method was difficult to perform remotely in the Shielded Cells because of the many connections required in the experimental apparatus. A simpler method was developed where the dried sludge slurry was treated with acid in a sealed Teflon vessel and the liberated $\mathrm{CO}_{2}$ was allowed to diffuse and react with the caustic for several days in the sealed vessel. To improve this method, an oxidizing agent (sodium persulfate) was added to oxidize any carbon that may have been in the sludge or salt in some form other than carbonate. To increase the efficiency of the method, the Analytical Development Section (ADS) developed a special separation technique to further isolate the ${ }^{14} \mathrm{C}$.[10] In this technique, the $\mathrm{CO}_{2}$ captured in the basic solutions in the Shielded Cells was purified further by acidifying aliquots of the solution. The liberated carbon dioxide was then captured in an amine-based capture agent. The agent was then slurried over into a liquid scintillation cocktail and analyzed by liquid scintillation analysis for ${ }^{14} \mathrm{C}$ beta particles. $\mathrm{A}{ }^{14} \mathrm{C}$ spike solution and a blank solution were also run through this process in parallel with triplicate samples. Based on the concentration of the spike recovery, the ${ }^{14} \mathrm{C}$ recovery was calculated. This method has been refined and can now be used as a routine analytical method by the ADS laboratories to analyze for ${ }^{14} \mathrm{C}$ in SRS samples. 


\subsection{Measured Concentrations in Sludge and Salt HLW Slurries}

Table 2-1 shows results of ${ }^{14} \mathrm{C}$ measurements in several SRS HLW samples.

Table 2-1 Results of Measurements of Carbon-14 in SRS HLW Samples

\begin{tabular}{||c|c|c|c|c||}
\hline $\begin{array}{c}\text { Tank/Year } \\
\text { Analyzed }\end{array}$ & Sample Type & $\begin{array}{c}\text { Weight \% } \\
\mathbf{1 4} \text { C (a) }\end{array}$ & $\begin{array}{c}\text { Number of } \\
\text { Samples }\end{array}$ & \%RSD \\
\hline $\begin{array}{c}\text { Tk. 8F, } \\
1983 \text { (b) }\end{array}$ & $\begin{array}{c}\text { Dried Sludge } \\
\text { Slurry }\end{array}$ & $4.5 \mathrm{E}-08$ & 3 & 40 \\
\hline $\begin{array}{c}\text { Tk. 15H, } \\
1983 \text { (b) }\end{array}$ & $\begin{array}{c}\text { Dried Sludge } \\
\text { Slurry }\end{array}$ & $5.6 \mathrm{E}-08$ & 6 & 46 \\
\hline $\begin{array}{c}\text { F-Area Cladding } \\
\text { Waste, 1983 (c) }\end{array}$ & $\begin{array}{c}\text { Dried Slurry of } \\
\text { Cladding Waste }\end{array}$ & $5.6 \mathrm{E}-08$ & 3 & 57 \\
\hline $\begin{array}{c}\text { SB1B } \\
1999(d)\end{array}$ & $\begin{array}{c}\text { Dried Sludge } \\
\text { Slurry }\end{array}$ & $9.9 \mathrm{E}-08$ & 3 & 67 \\
\hline $\begin{array}{c}\text { SB2 } 2002 \text { (e) } \\
\text { Tk. } 41\end{array}$ & $\begin{array}{c}\text { Dried Sludge } \\
\text { Slurry }\end{array}$ & $1.8 \mathrm{E}-07$ & 2 & 14 \\
\hline
\end{tabular}

(a) Concentration unit is weight percent Carbon-14 in total dried solids of the slurry.

(b) Results published in Reference 7.

(c) Cladding waste is the waste from caustic dissolution of the Al cladding of the SRS reactor fuels or targets. Results published in Reference 7.

(d) Results published in Reference 4.

(e) Results published in Reference 5.

(f) Results published in Reference 11.

The sludges and the cladding waste analyzed in 1983 were dried samples of highly washed SRS sludges known to contain high concentrations of aluminum. The principal source of ${ }^{14} \mathrm{C}$ in the waste was considered to be associated with aluminum because the aluminum cladding was in direct contact with moderator during irradiation. The moderator is a primary source of ${ }^{14} \mathrm{C}$ generated during irradiation.[7, 12] The sludges from Tanks $8 \mathrm{~F}$ and $15 \mathrm{H}$ were primarily from the caustic dissolution of the $\mathrm{Al}$ cladding on the reactor fuels and targets. These sludges were originally transferred to Tanks $8 \mathrm{~F}$ and $15 \mathrm{H}$ from $\mathrm{F}$ and $\mathrm{H}$ Area canyons, respectively. Consequently, samples from these two tanks were selected as "representative" waste to be analyzed for ${ }^{14} \mathrm{C}$. (It should be mentioned though that Tank $15 \mathrm{H}$ also received sludge from the $\mathrm{H}$ Area Modified Purex Process (HM) process that co dissolved the aluminum and uranium in nitric acid solution.) A sample of decladding waste from F-area was also obtained and analyzed for its ${ }^{14} \mathrm{C}$ content.

The primary purpose of the study by Fowler and Coleman [7] was to establish the amount of ${ }^{14} \mathrm{C}$ that would be released to the environment from the DWPF stack during processing of HLW sludge. This information was needed to support the design and permit applications for the DWPF. At the time these analyses were done, neither the WAPS for the repository nor the WCP to meet glass specifications were established. However, ${ }^{14} \mathrm{C}$ was not considered to be a significant radionuclide in the glass, based on known chemical properties of carbon compounds and the projected processing conditions to be used to prepare feed for subsequent melter operation. The total inventory in the sludge was estimated to be $6.8 \mathrm{Ci}$ and annual releases from the DWPF were estimated at $0.6 \mathrm{Ci}$ based on production forecasts at that 
time.[7] In these samples ${ }^{14} \mathrm{C}$ was determined by reacting the dried samples with $6 \mathrm{M} \mathrm{H}_{2} \mathrm{SO}_{4}$. The $\mathrm{CO}_{2}$ was swept into the caustic solution by a stream of nitrogen gas. The amount of ${ }^{14} \mathrm{C}$ was then determined by beta counting. Two out of three of these results have poor precision probably because of the loss of $\mathrm{CO}_{2}$ in the method and the necessity of having to use the efficiency factor determined using a standard ${ }^{14} \mathrm{C}$ solution.

The HLW samples analyzed in 1999 and later were slurries containing both sludges and HLW salt solutions. These were dissolved remotely in the Shielded Cells using Teflon vessels that could be tightly sealed using a special tightening device operated remotely in the Shielded Cells. Again the precision was poor due to loss of $\mathrm{CO}_{2}$ prior to sealing the vessels, even though they were sealed as quickly as possible in the Shielded Cells. In these analyses the oxidizing agent was added to the acidic solutions so all carbon compounds in the samples were oxidized to $\mathrm{CO}_{2}$. Consequently the results in Table 2-1 represent the total ${ }^{14} \mathrm{C}$ including the ${ }^{14} \mathrm{C}$ that may not have been originally in the form of carbonate. In Table 2-1 most of the concentrations of ${ }^{14} \mathrm{C}$ in the dried salt slurries are comparable to those in the dried sludge slurries. This suggests that a large fraction of the ${ }^{14} \mathrm{C}$ was soluble in the supernate of the sludges when they were initially transferred to a waste tank. Consequently most of the ${ }^{14} \mathrm{C}$ originally associated with the sludge has been transferred to the salt tanks for long term storage and will eventually be disposed as a component of saltstone. The results in Table 2-1 for SB1B and SB2 were used to show that ${ }^{14} \mathrm{C}$ was reportable in these two sludge batches.[4,5] 


\subsection{PRODUCTION OF CARBON-14 IN THE REACTORS AT SRS}

Before discussing the mechanisms of ${ }^{14} \mathrm{C}$ losses in the DWPF, it is helpful to discuss the modes of ${ }^{14} \mathrm{C}$ production in the SRS reactors. Also its possible chemical forms must be considered, especially since the reactor fuels and targets were dissolved and processed to recover the desired irradiation products in $\mathrm{F}$ and $\mathrm{H}$ Canyons. Knowing the chemical form of the ${ }^{14} \mathrm{C}$ in the $\mathrm{HLW}$ is critical to evaluating its loss from the DWPF during processing. The information in this section is based on an extensive literature search by the authors, their knowledge of SRS fuel and target dissolution processes in F-Area and H-Area canyons, and discussions with knowledgeable colleagues about the methods of production of reactor fuels and targets and the impurities in them that could produce the ${ }^{14} \mathrm{C}$ when the fuels and targets were irradiated. The detailed results of this effort are documented in a report written by Dr. John Fowler of JKLW Enterprises, Inc. For completeness that report in its entirety is attached as Appendix A of this report. Most of the discussions in Appendix A pertain to Section 3 of this report.

\subsection{Nuclear Reactions Producing Carbon-14}

Formation of ${ }^{14} \mathrm{C}$ in SRS fuels, targets and waste can come from the following thermal neutron transmutation reactions in the SRS reactors. The isotope ${ }^{14} \mathrm{~N}$ transmutes by a (n, p) reaction, the isotope ${ }^{17} \mathrm{O}$ through a $(\mathrm{n}, \alpha)$ reaction and the isotope ${ }^{13} \mathrm{C}$ through a $(\mathrm{n}, \gamma)$ reaction. Using elemental forms for the precursors, these three nuclear reactions are represented below with corresponding electron transfer reactions included to maintain a net charge balance. The asterisks indicate that the intermediate nuclei are in an excited state.

$$
\begin{aligned}
& { }^{14} \mathrm{~N}+{ }^{1} \mathrm{n} \rightarrow\left[{ }^{15} \mathrm{~N}\right]^{*} \rightarrow\left[{ }^{14} \mathrm{C}^{1-}\right]^{*}+{ }^{1} \mathrm{p}^{1+} \rightarrow{ }^{14} \mathrm{C}+{ }^{1} \mathrm{H} \\
& { }^{17} \mathrm{O}+{ }^{1} \mathrm{n} \rightarrow\left[{ }^{18} \mathrm{O}\right]^{*} \rightarrow\left[{ }^{14} \mathrm{C}^{2-}\right]^{*}+{ }^{4} \alpha^{2+} \rightarrow{ }^{14} \mathrm{C}+{ }^{4} \mathrm{He} \\
& { }^{13} \mathrm{C}+{ }^{1} \mathrm{n} \rightarrow\left[{ }^{14} \mathrm{C}\right]^{*} \rightarrow{ }^{14} \mathrm{C}+\gamma
\end{aligned}
$$

Radioactive ${ }^{14} \mathrm{C}$ could also have been produced by ternary fission of U-235 [13] in the SRS reactors, but this source is negligible compared to the other sources [12]. Although the overall charge balances of the nuclear reactions are preserved in the above equations, they do not reflect the chemical reactivity of the ionic ${ }^{14} \mathrm{C}$ species produced initially, nor do they address the chemical environment that could surround these species when they are produced. For the SRS reactors, the transmutation of ${ }^{13} \mathrm{C}$ to ${ }^{14} \mathrm{C}$ is negligible compared to the reactions involving ${ }^{14} \mathrm{~N}$ and ${ }^{17} \mathrm{O}$. This is because of the low abundance of ${ }^{13} \mathrm{C}$ and its low thermal neutron adsorption cross section.[6] Except for metal-oxide targets used in the SRS reactors for special irradiations, nitrogen-containing species dominate as precursors for ${ }^{14} \mathrm{C}$ in fuels and targets used at the SRS.[12] These targets were oxides of Th, Pu, and Np. As shown above, the oxide could absorb a neutron and produce ${ }^{14} \mathrm{C}$.

All the above nuclear transformations form ${ }^{14} \mathrm{C}$ atoms that initially have abnormally high kinetic energies or electrical charge or both.[14] For example the kinetic energy of the ${ }^{14} \mathrm{C}$ resulting from the (n, p) reaction of ${ }^{14} \mathrm{~N}$ is acquired as a result of the requirement of conservation of momentum in the emission of the proton. The charge results from the emission of a proton. Regardless of its chemical form, when ${ }^{14} \mathrm{~N}$ absorbs a thermal neutron, an excited ${ }^{15} \mathrm{~N}$ nucleus is formed. To gain stability this nucleus decays by emitting a proton. The energy of this proton is $625 \mathrm{KeV}$.[15] Based on the conservation of momentum, the energy of the recoil ${ }^{14} \mathrm{C}$ atom is $45 \mathrm{KeV}$ (the energy of the proton divided by the mass of the ${ }^{14} \mathrm{C}$ or $625 / 14)$. Consequently an energetic carbide ion $\left(C^{-}\right)$is formed that can deposit in the metallic matrix of the fuel or target. Chemical bonds are rarely greater than $5 \mathrm{eV}$; consequently the carbide ion has sufficient energy to break many chemical bonds in the matrix including its parent bonds.[16] After the $\mathrm{C}^{-}$ ion loses its excess kinetic energy, it either reacts with some species in the matrix or is trapped at a lattice vacancy. 
Possible nitrogen- and oxygen-containing species that could be present in fuels, targets and moderator used in the reactor must be considered to identify possible chemical forms of ${ }^{14} \mathrm{C}$ species that could be generated during reactor operations at SRS.

\subsection{Possible Sources of Carbon-14 Precursors in SRS Reactors}

To identify the possible chemical species containing ${ }^{14} \mathrm{C}$, it is necessary to identify the chemical form of the $\mathrm{N}$ and $\mathrm{O}$ species that were irradiated in the SRS reactors. Based on purchase specifications for materials used to fabricate natural and enriched uranium fuels and depleted uranium targets, only trace levels of compounds containing nitrogen and/or oxygen were present in the bulk metals obtained from vendors.[17] At SRS all the reactor fuels and targets had a thin cladding of aluminum on them to inhibit corrosion while being irradiated in the reactors moderated with heavy water. In later operations a thin plating of nickel was placed between the uranium slugs and aluminum cladding to facilitate heat transfer during the irradiations. Nitric acid was used extensively during the cladding of uranium slugs and other targets. Even though the fuels and targets were rinsed with water after each etching with nitric acid, trace levels of nitrate salts of $\mathrm{U}, \mathrm{Ni}$ and $\mathrm{Al}$ may have been retained on the surface of the plated uranium slugs when they were sealed in the aluminum cans. Residues of $\mathrm{UO}_{2}\left(\mathrm{NO}_{3}\right)_{2}, \mathrm{Ni}\left(\mathrm{NO}_{3}\right)_{2}$ and $\mathrm{Al}\left(\mathrm{NO}_{3}\right)_{3}$ are all possible ${ }^{14} \mathrm{C}$ precursors.

Extrusion techniques used to fabricate fuel tubes and targets are likely to introduce additional impurities that could lead to production of ${ }^{14} \mathrm{C}$ during irradiation.[17] In addition to nitrate species other possible species present in both fuels and targets that could lead to the formation of ${ }^{14} \mathrm{C}$ are:

- $\mathrm{Al}_{2} \mathrm{O}_{3}, \mathrm{NiO}$ and $\mathrm{UO}_{2}$ formed on bulk metal surfaces during fabrication of fuels and targets;

- Traces of $\mathrm{Al}_{2} \mathrm{O}_{3}, \mathrm{AlN}$ and $\mathrm{UO}_{2}$ dispersed in the bulk metals that were retained when the metals were produced;

- Traces of $\mathrm{N}_{2}$ and $\mathrm{O}_{2}$ dissolved in the bulk metals or inadvertently trapped during fabrication of fuel and target elements;

The chemistry of the recoiling ${ }^{14} \mathrm{C}$ is indeed complicated. For example, when the compounds $\mathrm{NH}_{4} \mathrm{NO}_{3}$ and $\left(\mathrm{NH}_{2}\right)_{2} \mathrm{CO}$ were neutron irradiated, ${ }^{14} \mathrm{CO},{ }^{14} \mathrm{CO}_{2}$ and $\mathrm{HCN}$ containing ${ }^{14} \mathrm{C}$ were formed in both irradiated salts.[16] Considering the possible oxygen and nitrogen containing species that are present in the fuels and targets, the excited ${ }^{14} \mathrm{C}$ after losing most of its energy through collisions could eventually undergo complex chemical reactions to form the stable chemical species that would be trapped at vacancies in the targets or fuel. Examples of the stable species are $\mathrm{CO}, \mathrm{CO}_{2}, \mathrm{CO}_{3}{ }^{\circ}, \mathrm{CN}^{-}$, and $\mathrm{C}_{2}{ }^{=}$, which is the carbide ion. It may even be possible that individual ${ }^{14} \mathrm{C}$ atoms become trapped in the matrix after they reach thermal energies.

\subsection{Chemical Behavior of Carbon-14 Species During Dissolution of SRS Reactor Fuels and Targets}

Two types of dissolutions were used at SRS to recover the irradiated fuel or target materials. One used hot nitric acid to dissolve the cladding and the fuel or target materials simultaneously. The other used hot caustic to dissolve only the aluminum cladding. After the dissolution, the caustic solution containing aluminate was decanted and hot nitric acid was used to dissolve the fuel or target materials. All dissolutions occurred in boiling solutions.[18] Consideration of the chemistry of carbon suggests that only the caustic dissolution will result in ${ }^{14} \mathrm{C}$ being transferred to the SRS waste tanks. 
During nitric acid dissolutions of fuel and targets, the nitric acid reacts with ${ }^{14} \mathrm{C}$ species contained in the metal matrices to yield volatile species in the dissolver: These reactions include the reactions of carbides that may be present such as $\mathrm{Ni}$ or $\mathrm{U}$ carbide.[19]

$$
\begin{aligned}
& \mathrm{HNO}_{3}+\mathrm{Ni}_{3}{ }^{14} \mathrm{C} \rightarrow \text { mixture of hydrogen, hydrocarbons }+\mathrm{Ni}\left(\mathrm{NO}_{3}\right)_{2} \\
& 4 \mathrm{HNO}_{3}+\mathrm{U}^{14} \mathrm{C} \rightarrow \mathrm{UO}_{2}\left(\mathrm{NO}_{3}\right)_{2}+\mathrm{NO}_{2}+{ }^{14} \mathrm{CH}_{4}
\end{aligned}
$$

The carbonates and cyanides along with $\mathrm{CO}_{2}$ and $\mathrm{CO}$ containing ${ }^{14} \mathrm{C}$ that are present in the $\mathrm{U}$ and $\mathrm{Ni}$ metal matrices, would react with nitric acid to produce volatile ${ }^{14} \mathrm{CO}_{2}$ and $\mathrm{H}^{14} \mathrm{CN}$, as shown in the reactions below. Since the dissolver solutions are boiling, the volatile carbon species are not likely to remain in the final solutions that are neutralized and transferred to a HLW storage tank.

$$
\begin{aligned}
& 2 \mathrm{HNO}_{3}+{ }^{14} \mathrm{CO}_{3}{ }^{2-} \rightarrow 2 \mathrm{NO}_{3}{ }^{1-}+{ }^{14} \mathrm{CO}_{2}+\mathrm{H}_{2} \mathrm{O} \\
& \mathrm{HNO}_{3}+{ }^{14} \mathrm{CN}^{-} \rightarrow \mathrm{H}^{14} \mathrm{CN}+\mathrm{NO}_{3}{ }^{-}
\end{aligned}
$$

In the caustic dissolution process, any of the species containing ${ }^{14} \mathrm{C}$ present in the cladding would react during dissolution of the aluminum to yield $\mathrm{NaCN}, \mathrm{CH}_{4}$ and $\mathrm{Na}_{2} \mathrm{CO}_{3}$ according to these reactions:

$$
\begin{aligned}
& \mathrm{Al}\left({ }^{14} \mathrm{CN}\right)_{3}+4 \mathrm{NaOH} \rightarrow 3 \mathrm{Na}^{14} \mathrm{CN}+\mathrm{NaAlO}_{2}+2 \mathrm{H}_{2} \mathrm{O} \\
& \mathrm{Al}_{4}\left({ }^{14} \mathrm{C}\right)_{3}+4 \mathrm{NaOH}+4 \mathrm{H}_{2} \mathrm{O} \rightarrow 4 \mathrm{NaAlO}_{2}+3{ }^{14} \mathrm{CH}_{4} \\
& \mathrm{Al}_{2}\left({ }^{14} \mathrm{CO}_{3}\right)_{3}+8 \mathrm{NaOH} \rightarrow 3 \mathrm{Na}_{2}{ }^{14} \mathrm{CO}_{3}+2 \mathrm{NaAlO}_{2}+4 \mathrm{H}_{2} \mathrm{O}
\end{aligned}
$$

During caustic dissolution of aluminum, ammonia, methane, hydrogen and other non-condensable gases are formed and are released to the Vessel Vent System, and eventually to the general environment from the canyon stacks. The carbonates and cyanides would be retained in the caustic solution as soluble or insoluble compounds. These would eventually reach the HLW Tanks since these solutions are not chemically processed further.

From the above discussion we conclude that the principle ${ }^{14} \mathrm{C}$ species in the HLW are carbonate and possibly cyanide salts. The fate of these in DWPF processing will now be discussed. 
WSRC-TR-2004-00629

Revision 0

\subsection{MECHANISMS FOR LOSS OF CARBON-14 DURING DWPF PROCESSING}

In the DWPF the HLW slurries are processed to immobilize the solids in the waste in a borosilicate glass. There are three processes in the DWPF where the ${ }^{14} \mathrm{C}$ can be lost from the sludge slurry. These are the SRAT process, the SME process, and the vitrification process that occurs in the melter. These three processes are discussed below.

\subsection{Losses During SRAT Processing}

In the SRAT process, the carbon that is present in the sludge slurry as carbonate is converted to $\mathrm{CO}_{2}$ that is evolved in the off-gas from the SRAT vessel. Any carbon present as cyanide ion is converted to volatile HCN that is also evolved in the off-gas of the SRAT vessel. The conversion of carbonate and evolution of $\mathrm{CO}_{2}$ will be discussed first.

In the SRAT, both nitric and formic acids are added to the waste slurry. The purpose of acid additions are to adjust the rheology of the slurry to render it easier to mix and pump and to reduce mercury salts to mercury metal so it can be steam-stripped from the waste prior to sending the treated slurry to the DWPF melter. In the DWPF SRAT process, the acids are added to hot slurry $\left(\sim 93^{\circ} \mathrm{C}\right)$. The acidified slurry is then boiled and water is evaporated from the slurry to reduce the volume of the slurry to its original volume before the acids were added. This requires $\sim 8$ hours processing time in the DWPF. [20] The slurry is then boiled under reflux conditions at $\sim 101-103^{\circ} \mathrm{C}$ for 12 hours to steam-strip metallic mercury during this reflux period. [20] Many small scale SRAT tests have been performed with both simulated HLW sludges and with actual radioactive HLW sludges. In the Shielded Cells of SRNL the entire DWPF process is performed on each radioactive sludge batch as part of qualifying each batch for processing in the DWPF. In the small scale tests, the DWPF SRAT process conditions are duplicated as well as practical to validate the results of tests completed with nonradioactive sludge. During these tests, the offgases of the SRAT are swept with air through a gas chromatograph to determine the composition of the gas being evolved. The air purge contains a known concentration of helium so the concentrations of the evolved gases can be calculated. In these tests, the concentrations of $\mathrm{CO}_{2}, \mathrm{H}_{2}$, and $\mathrm{N}_{2} \mathrm{O}$ were measured as a function of processing time. Figure 4-1 shows the concentration of $\mathrm{CO}_{2}$ in the evolved gas during the qualification test with SB2.[21] The trends for the $\mathrm{CO}_{2}$ concentrations shown in Figure 4-1 are typical to those observed in all the SRAT tests with both simulated and actual radioactive sludges. In the test with $\mathrm{SB} 2$ the $\mathrm{pH}$ of the slurry was also measured during the SRAT process and the $\mathrm{pH}$ results are also shown in Figure 4-1. 


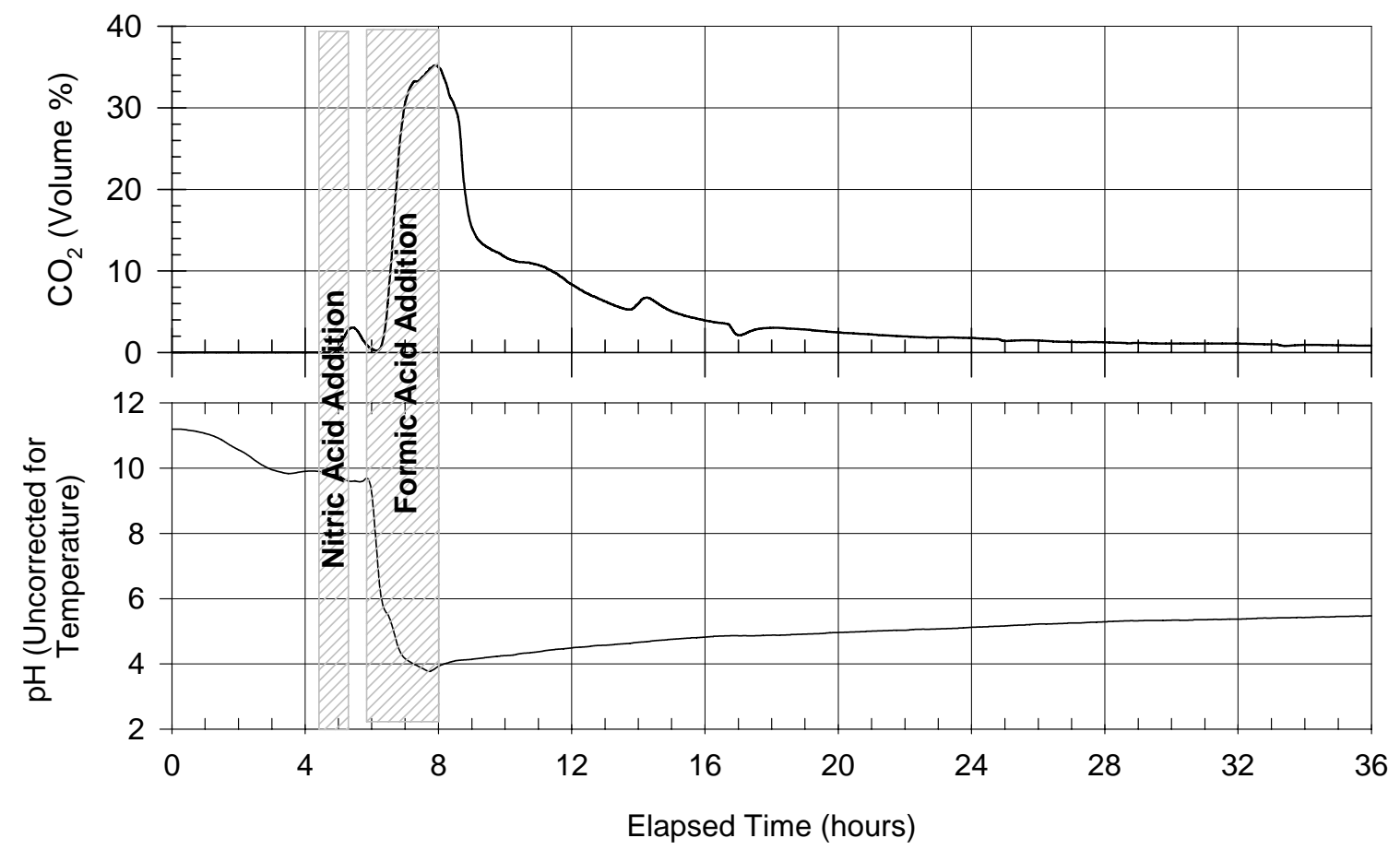

Figure 4-1 Carbon Dioxide Evolution and pH Changes during the SRAT Process Performed in the SRNL Shielded Cells to Qualify SB2 for DWPF Processing

(Taken from Reference 21)

We will now discuss the results in Figure 4-1 in some detail. The results for $\mathrm{CO}_{2}$ evolution are completely consistent with the affect of $\mathrm{pH}$ on the chemistry of a carbonate/bicarbonate/carbonic acid system. In the SRAT tests in the Shielded Cells, as in the DWPF, the slurries in the SRAT are heated to $93^{\circ} \mathrm{C}$ prior to the addition of the acids. In Figure 4-1, zero time indicates the time the heater was activated and stirring of the slurry began. During this time no $\mathrm{CO}_{2}$ was evolved and the $\mathrm{pH}$ changed from 11.5 to 10 due to the effect of temperature on $\mathrm{pH}$ readings. Fifty-weight percent nitric acid was added first, followed by the addition of concentrated formic acid. There was little change in the $\mathrm{pH}$ during nitric acid addition presumably because of the excess soluble hydroxide initially in the slurry. Only a small amount of $\mathrm{CO}_{2}$ was evolved probably due to regions of short lived low $\mathrm{pH}$ slurry where the 50 -wt\% nitric acid hit the solution. At the initial $\mathrm{pH}$ values of the sludges (11-12) the principle form of carbonic acid is the carbonate anion. The carbonate may be in the sludge supernate as soluble carbonates or in the sludge solids as insoluble carbonates of $\mathrm{Ba}$, Ca, and $\mathrm{Sr}$. When formic acid was added, the $\mathrm{pH}$ decreased dramatically to 4 during the two hours of addition. As the $\mathrm{pH}$ dropped to 4 there was a considerable release of $\mathrm{CO}_{2}$ increasing to $\sim 35$ volume percent of the measured gas at 8 hours. Calculations based on experimental data have shown that at $\mathrm{pH}$ values below 6 , the insoluble carbonates are completely soluble. [22] At a pH of 6, the soluble species are $70 \%$ carbonic acid and 30\% bicarbonate with only a trace of carbonate.[23] As the $\mathrm{pH}$ is lowered further in the SRAT, more bicarbonate is converted to carbonic acid. For example at a $\mathrm{pH}$ of 4, only a trace of bicarbonate exists in the solution.[23] At these low $\mathrm{pH}$ values, the carbonic acid dissociates to dissolved carbon dioxide and water. It has been calculated that $<1 \%$ exists as carbonic acid and $>99 \%$ as soluble free $\mathrm{CO}_{2}$.[24] The $\mathrm{CO}_{2}$ can easily be removed from the solution by boiling. As shown in Figure 4-1, the concentration of $\mathrm{CO}_{2}$ then continuously decreased 
(except for some slight variations) to concentrations of $<1 \%$ for the remainder of the 36 hour SRAT test. Note that the concentration did not increase even when the temperature was increased at $~ 15$ hours to initiate boiling of the slurry. Based on the above discussion, essentially all of the carbon present as carbonate (including ${ }^{14} \mathrm{CO}_{3}{ }^{2-}$ ) has been evolved from the slurry at the end of the SRAT process. Any carbon remaining in the slurry would be in the form of formate or oxalate salts, coal (if present in the feed slurry) and residues of degraded extractants and resins. The ${ }^{14} \mathrm{C}$ content of these materials would approximate "natural" isotopic distribution, since all of these materials are introduced in upstream chemical processes used in $\mathrm{F}$ and $\mathrm{H}$ Areas or in the formic acid treatment used in the SRAT. These chemicals were not irradiated in the reactors and would not be "enriched" in ${ }^{14} \mathrm{C}$.

\subsection{Losses During SME Processing}

In the DWPF SME process, water from canister decontamination operations is added to the SME. This water is then removed by boiling. The correct amount of glass forming frit is then added as a slurry in dilute formic acid. The SME process was also simulated in the Shielded Cells using the product of the SRAT run for the qualification of SB2. During this simulation the evolution of $\mathrm{CO}_{2}$ and the $\mathrm{pH}$ of the slurry were also monitored. Carbon dioxide evolution and $\mathrm{pH}$ changes during the SME process simulation in the SRNL qualification run for SB2 are shown in Figure 4-2.[25]
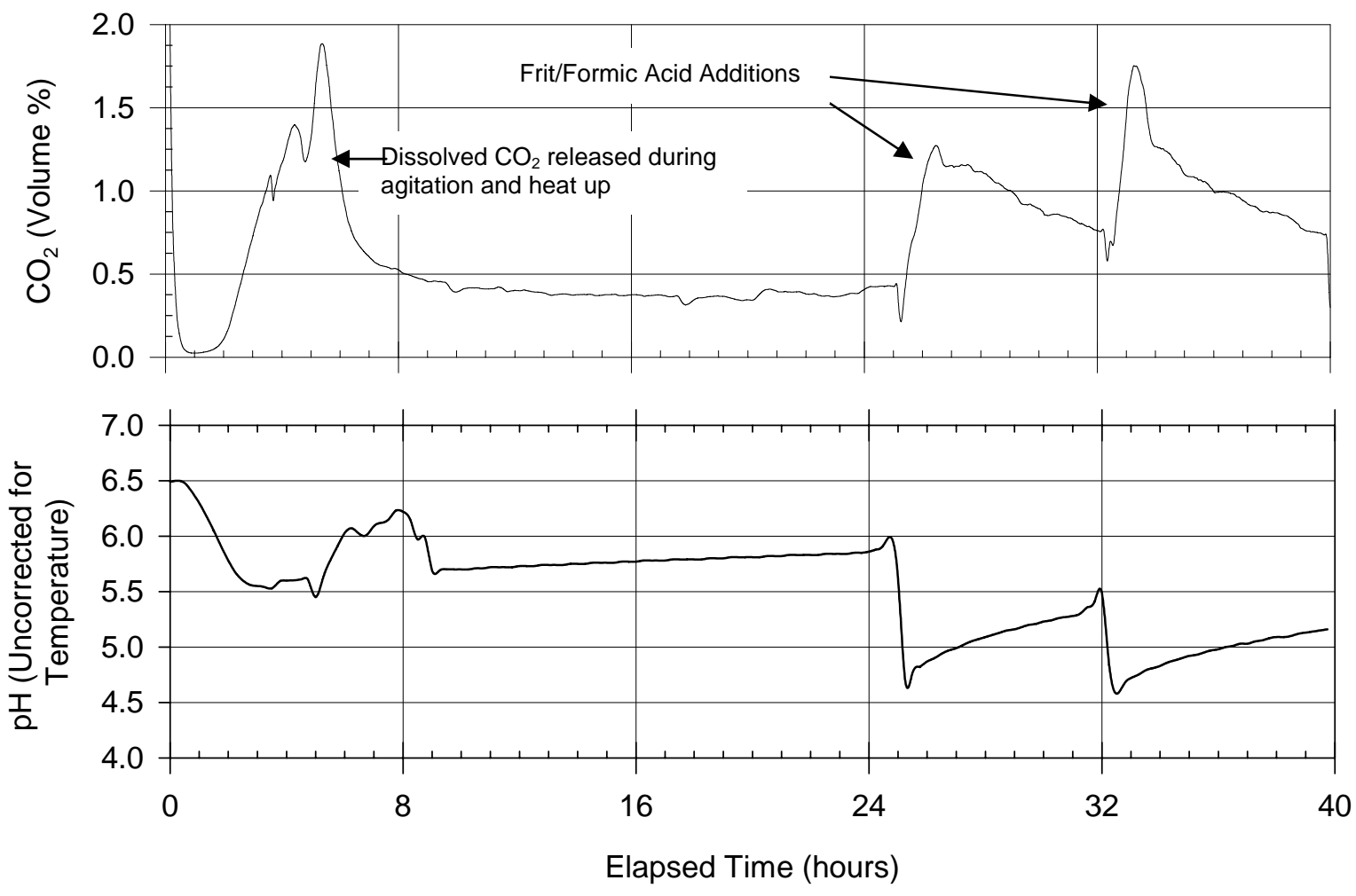

Figure 4-2 Carbon Dioxide Evolution and pH Changes during the SME Process Performed in the SRNL Shielded Cells to Qualify SB2 for DWPF Processing

(Taken from Reference 25)

In Figure 4-2, as in Figure 4-1, zero time is the time that agitation and heating of the SME contents was initiated. After $\sim 3.5$ hours the contents were boiling. At this time water was added to the vessel to simulate the addition of water from decontamination of five canisters in the DWPF. Over the next 19 
hours this water was boiled off. During the first 4 hours of SME processing, $\mathrm{CO}_{2}$ was evolved. This $\mathrm{CO}_{2}$ was probably absorbed from the air while the vessel sat unsealed inside the Shielded Cells during the time between the SRAT and SME cycle, although radiolytic decomposition of formate or oxalate salts in the radioactive slurry is also a possible source of $\mathrm{CO}_{2}$. Note that this was a much smaller amount of $\mathrm{CO}_{2}$ $(\sim 1.8 \%)$ than was evolved from the SRAT where concentration of $\mathrm{CO}_{2}$ reached $\sim 30$ volume percent of the gas purged from the vessel (See Figure 4-1). As shown in Figure 4-2, the $\mathrm{CO}_{2}$ leveled off to a constant concentration of $\sim 0.4$ volume percent until frit addition. Two frit/formic acid additions were made as indicated in Figure 4-2. With each addition, the $\mathrm{pH}$ dropped approximately one unit while the $\mathrm{CO}_{2}$ increased. This $\mathrm{CO}_{2}$ could have resulted from decomposition of the formic acid that was added with the frit. The SME process is the second process where ${ }^{14} \mathrm{C}$ that was present at $\mathrm{CO}_{2}$ would be lost to the off gas. In the DWPF SME, the average time of boiling is $~ 60$ hours so there is ample time for the evolution of $\mathrm{CO}_{2} \cdot[20]$

\subsection{Carbon-14 Losses During the Melting Process}

The DWPF melter operates at $1150^{\circ} \mathrm{C}$. The temperature of the melter plenum vapor space is kept at 600 $800^{\circ} \mathrm{C}$ with electric heaters.[26] As the sludge/frit slurry mixture is fed to the melter, a cold cap forms on the surface of the melt. A four-stage cold cap model has been developed that describes the melting of the feed solids.[27] The chemical reactions occurring at each stage have been described to develop a oxidation/reduction correlation for vitrifying Sludge Batch 3 in the DWPF.[28] The temperature of the first two Stages is 700 to $850^{\circ} \mathrm{C}$. In these two stages air is present so there is sufficient oxygen to support the oxidation of organic compounds that may be in the waste being fed to the melter. In Stages 3 and 4, the amount of air is limited, but processes involving reduction of metallic oxides can occur to oxidize carbon compounds.[28] The temperature of Stage 3 is hypothesized to be $1050^{\circ} \mathrm{C}$ while Stage 4 is at $1150^{\circ} \mathrm{C}$, the operating temperature of the melter. The nominal residence time in the melter is about 66 hours so there is ample time for these oxidation/reduction reactions to occur.[26].

As mentioned before, carbon is present in several different forms in the waste tanks.

- Oxalate salts from processes and equipment decontamination in Separations areas, reactor areas and the Tank Farms;

- Formate salts primarily from melter feed preparation in the SRAT and formic acid denitration tests in H Area;

- Elemental carbon (coal) that was transferred to Tank 7F when a sand filter in a reactor area failed;

- Various soluble and insoluble organic compounds (e.g., organic resins and degraded extractants, such as dibutylphosphate.);

- Carbonate and possibly cyanide salts from caustic dissolution of the aluminum cladding on U fuel and target slugs: and

- Carbonate salts formed by absorption of $\mathrm{CO}_{2}$ from air used to purge waste tanks.

Carbonate dominates as the primary chemical form of carbon in stored waste. In the waste tanks, the total carbonate inventory will continue to increase as $\mathrm{CO}_{2}$ in air purges is absorbed by the caustic waste to form sodium carbonate. Conversely, since $\mathrm{CO}_{2}$ in air contains carbon with a "natural" isotopic distribution, any salt waste isotopically "enriched" in ${ }^{14} \mathrm{C}$ from irradiation is gradually diluted as carbonate from $\mathrm{CO}_{2}$ absorption increases. As discussed above, processes used to prepare feed for the melter effectively remove carbonate species from the melter feed, thus eliminating the primary potential source of ${ }^{14} \mathrm{C}$ from the slurry that is fed to the melter. The chemistries of carbon compounds remaining in the melter are discussed below. 
Formate and oxalate salts have been sent to the waste tanks from Separations, Reactors and other miscellaneous operations, including DWPF recycled waste (see Appendix A). Although cyanide has never been identified as a waste component, it may be present in low concentrations, probably as soluble cyanide or $\mathrm{Hg}(\mathrm{CN})_{2}$. If cyanide is present, the most likely source going to $\mathrm{HLW}$ is the regeneration of resins used to remove contaminants from the Receiving Basins for Offsite Fuels (RBOF). The regeneration of the resins would remove radioactive cyanide from the resins. This cyanide would have been transferred to a HLW tanks along with other contaminants in the RBOF water. Interaction with Hg contained in the waste stored in the H-Area Tank Farm is assumed to have formed $\mathrm{Hg}(\mathrm{CN})_{2}$. The expected chemistries in the melter for these various carbon compounds are considered below.

\subsubsection{Decomposition of Formate and Oxalate Salts}

Based on known chemistry and physical properties, alkali and alkaline earth formate salts and oxalate salts will either react with oxidizing species in the cold cap and/or the surface of the melt pool or decompose. Sodium formate is the principal formate salt in the melter feed due to the high concentrations of sodium. It is used to describe the various reactions of formate salts that likely occur in the cold cap at $700-850^{\circ} \mathrm{C}$. Formate salts react with insoluble metal oxides (e.g., $\mathrm{Fe}_{2} \mathrm{O}_{3}$ ) to yield metal oxides in lower oxidation states, or with $\mathrm{NaNO}_{3}$ to yield $\mathrm{NaHCO}_{3}$ and $\mathrm{NaNO}_{2}$. These two compounds subsequently decompose in the cold cap (at $270^{\circ} \mathrm{C}$ and $320^{\circ} \mathrm{C}$, respectively, for the pure compounds) to yield $\mathrm{Na}_{2} \mathrm{O}$, oxides of nitrogen, $\mathrm{CO}_{2}$ and water. The following equations would apply in the cold cap or the melt surface:

$$
\begin{aligned}
& 2 \mathrm{NaCOOH}+2 \mathrm{Fe}_{2} \mathrm{O}_{3} \rightarrow 4 \mathrm{FeO}+2 \mathrm{CO}_{2}+\mathrm{Na}_{2} \mathrm{O}+\mathrm{H}_{2} \mathrm{O} \\
& 2 \mathrm{NaCOOH}+2 \mathrm{NaNO}_{3} \rightarrow 2 \mathrm{NaNO}_{2}+2 \mathrm{NaHCO}_{3} \\
& \mathrm{NaNO}_{2}+2 \mathrm{NaHCO}_{3} \rightarrow 2 \mathrm{Na}_{2} \mathrm{O}+\mathrm{NO}+\mathrm{NO}_{2}(\mathrm{~g}) \\
& \mathrm{NaO}_{2}+\mathrm{CH}_{2} \mathrm{O}
\end{aligned}
$$

If formate salts are not completely consumed in reactions, such as the above, they thermally decompose to oxalate salts and hydrogen. For example, sodium formate decomposes at about $200^{\circ} \mathrm{C}$.[29]

$$
2 \mathrm{NaCOOH} \rightarrow \mathrm{Na}_{2} \mathrm{C}_{2} \mathrm{O}_{4}+\mathrm{H}_{2}
$$

Sodium oxalate is also a component of the melter feed. Sodium oxalate also reacts with insoluble metal oxides (e.g., $\mathrm{Fe}_{2} \mathrm{O}_{3}$ ) in the cold cap and on the melt pool surface to yield metal oxides in lower oxidation states, or with $\mathrm{NaNO}_{3}$ to yield $\mathrm{Na}_{2} \mathrm{O}$, oxides of nitrogen and $\mathrm{CO}_{2}$ :

$$
\begin{aligned}
& \mathrm{Na}_{2} \mathrm{C}_{2} \mathrm{O}_{4}+\mathrm{Fe}_{2} \mathrm{O}_{3} \rightarrow 2 \mathrm{FeO}+\mathrm{Na}_{2} \mathrm{O}+2 \mathrm{CO}_{2} \\
& 2 \mathrm{Na}_{2} \mathrm{C}_{2} \mathrm{O}_{4}+2 \mathrm{NaNO}_{3} \rightarrow 3 \mathrm{Na}_{2} \mathrm{O}+\mathrm{NO}+\mathrm{NO}_{2(\mathrm{~g})}+4 \mathrm{CO}_{2}
\end{aligned}
$$

In the absence of an oxygen source, oxalate salts decompose in the range of $400-550^{\circ} \mathrm{C}$, yielding a metal carbonate and $\mathrm{CO}$ :

$$
\mathrm{Na}_{2} \mathrm{C}_{2} \mathrm{O}_{4} \rightarrow \mathrm{Na}_{2} \mathrm{CO}_{3}+\mathrm{CO}
$$

\subsubsection{Decomposition of Mercuric Cyanide}

Mercuric cyanide, $\mathrm{Hg}(\mathrm{CN})_{2}$, if present, thermally decomposes at $\sim 320^{\circ} \mathrm{C}$ to yield $\mathrm{Hg}$ and cyanogen, $(\mathrm{CN})_{2 .}$ [19] These would evolve from the cold cap in the melter:

$$
\mathrm{Hg}(\mathrm{CN})_{2} \rightarrow \mathrm{Hg}_{(\mathrm{g})}+(\mathrm{CN})_{2}
$$


Cyanogen readily burns in oxygen to yield oxides of nitrogen and oxides of carbon, and would be destroyed in the plenum space of the melter. In fact, a stoichiometric mixture of $\mathrm{O}_{2}$ and $(\mathrm{CN})_{2}$ burns to produce one of the hottest flames $\left(\sim 5050^{\circ} \mathrm{K}\right)$ known from a chemical reaction [30]:

$$
(\mathrm{CN})_{2(\mathrm{~g})}+4 \mathrm{O}_{2} \rightarrow 2 \mathrm{CO}_{2}+2 \mathrm{NO}_{2}
$$

\subsection{3}

\subsubsection{Decomposition of Carbonate and Bicarbonate Salts}

If carbonate or bicarbonate salts survive the SRAT and SME processes and reach the melter, the combination of heat, steam and acid in the feed to the melter will smoothly decompose any surviving carbonates or bicarbonates to metal oxides and carbon dioxide. However, dry carbonates formed by thermal decomposition of alkali oxalates may likely persist in the cold cap until they reach the surface of the melt pool. For example, sodium carbonate does not decompose until it reaches a temperature of 800$900^{\circ} \mathrm{C}$, while sodium bicarbonate decomposes at $270{ }^{\circ} \mathrm{C}$.[31]

$$
\begin{aligned}
& \mathrm{Na}_{2} \mathrm{CO}_{3} \rightarrow \mathrm{Na}_{2} \mathrm{O}+\mathrm{CO}_{2} \\
& \mathrm{NaHCO}_{3} \rightarrow \mathrm{Na}_{2} \mathrm{O}+2 \mathrm{CO}_{2(\mathrm{~g})}+\mathrm{H}_{2} \mathrm{O}
\end{aligned}
$$

\subsubsection{Decomposition of Elemental Carbon}

Elemental carbon, if present in the waste, is relatively inert at ambient temperature and is not affected significantly by aqueous solutions of dilute acids or bases. It can be partially oxidized by hot, concentrated acids such as nitric acid. [29] When carbon is heated to higher temperatures $\left(>200^{\circ} \mathrm{C}\right)$, it can react with a number of substances, including steam. It combines with oxygen with the liberation of considerable heat to give a mixture of carbon monoxide and carbon dioxide, with the relative yields of these products being dependent upon the temperature and the proportions of the reactants. Carbon monoxide is formed almost quantitatively by the combustion of carbon in an insufficient supply of air at $1000^{\circ} \mathrm{C}$; at temperatures in the neighborhood of $500^{\circ} \mathrm{C}$, carbon dioxide is practically the sole product, even when carbon is in excess.[19] Elemental $\mathrm{C}$ would react in the cold cap with oxygen to generate $\mathrm{CO}_{2}$ as the feed slurry is introduced into the DWPF melter:

$$
\mathrm{C}+\mathrm{O}_{2(\mathrm{~g})} \rightarrow \mathrm{CO}_{2}
$$




\subsection{MEASUREMENT OF CARBON-14 IN SB1B GLASS}

\subsection{Measurement Technique and Result}

The concentration of ${ }^{14} \mathrm{C}$ was measured in a glass sample that was taken from the pour stream of the melter during processing SB1B. This sample was taken while filling canister S01142 in the DWPF. This was the 222nd canister filled during the SB1B campaign. Two reports have been published. The first presents the nonradioactive composition [32] and the second, the radioactive composition [33]. The results for ${ }^{14} \mathrm{C}$ were presented in the second report, but will be discussed in some detail here to calculate the fraction of the ${ }^{14} \mathrm{C}$ loss in DWPF processing.

To determine the ${ }^{14} \mathrm{C}$ concentration, two samples of crushed glass sieved to -200 mesh glass were dissolved remotely in the Shielded Cells in sealed Teflon vessels by the standard ADS mixed acid procedure.[34] The method was modified to collect and measure the ${ }^{14} \mathrm{C}$ based on the technique used to measure ${ }^{14} \mathrm{C}$ in the sludge samples.[10] Sodium persulfate (with a silver salt added as a catalyst) was added to the acid solution to oxidize any carbon that is not present as carbonate to $\mathrm{CO}_{2}$. A caustic solution contained in a separate small open vial was also placed in the Teflon vessel to capture any $\mathrm{CO}_{2}$ produced by the oxidation and the acid dissolution. Two vessels containing known amounts of ${ }^{14} \mathrm{C}$ standard were treated identically to those that contained the glass. The vessels were sealed as quickly as possible after the mixed acids were added to minimize any loss of $\mathrm{CO}_{2}$. After heating in an oven at $90^{\circ} \mathrm{C}$ for two hours to dissolve the glass, the vessels were allowed to stand in the Shielded Cells for two days to allow $\mathrm{CO}_{2}$ to diffuse and dissolve in the caustic solution. The vessels were then opened. The caustic solutions were transferred to sample vials and transported to the ADS for additional treatment to separate and isolate ${ }^{14} \mathrm{C}$ from other beta emitters. The aliquots of the purified solutions were then used to prepare scintillation cocktails and counted for the ${ }^{14} \mathrm{C}$ beta particles.

Carbon-14 beta particles were definitely detected in both standard solutions although the yields were low. Carbon-14 beta particles were not detected in either dissolution of the two glass samples. Results of the dissolution tests in which a standard solution of ${ }^{14} \mathrm{C}$ was added indicated that the method should have captured ${ }^{14} \mathrm{C}$ if it were present in the glass. (Visual observation of the Teflon vessels after dissolution of the glass showed that all the glass had been dissolved.)

Minimum detection limits for ${ }^{14} \mathrm{C}$ were calculated based on the counting efficiency and the yields measured with the standards. Concentrations of the ${ }^{14} \mathrm{C}$ were then calculated based on the minimum detection limit for ${ }^{14} \mathrm{C}$ in the two glass samples. The minimum detection limit is the lowest concentration of ${ }^{14} \mathrm{C}$ in the glass that could be detected using this measurement technique. Since ${ }^{14} \mathrm{C}$ was not detected, the maximum calculated concentration in the glass was less than this calculated value. The maximum calculated concentration in the glass based on the minimum detection limit is presented in Table 5-1 along with the concentration of ${ }^{14} \mathrm{C}$ measured in the dried sludge slurry that had been measured earlier in samples of the dried sludge slurry from SB1B campaign. The results show that the average concentration of ${ }^{14} \mathrm{C}$ in SB1B glass was less than $1.7 \mathrm{E}-09$ weight percent. The range was rather large due to the range in the two yields for ${ }^{14} \mathrm{C}$ in these dissolutions. The concentrations ranged from $<2.4 \mathrm{E}-09$ weight percent down to $<8.5 \mathrm{E}-10$ weight percent. To calculate the fraction of ${ }^{14} \mathrm{C}$ not immobilized in the glass, the predicted concentration of ${ }^{14} \mathrm{C}$ in the glass must be calculated after accounting for the dilution of the sludge slurry in the DWPF by the addition of the glass forming frit. This prediction and calculation are discussed in the next two sections. 
WSRC-TR-2004-00629

Revision 0

Table 5-1 Results of Measurements of C-14 in Samples of SB1B Crushed Glass and Dried SB1B Slurry

\begin{tabular}{||c|c|c|c|c||}
\hline $\begin{array}{c}\text { Sample and Year } \\
\text { Analyzed }\end{array}$ & Sample Type & $\begin{array}{c}\text { Average } \\
\text { Weight \% } \\
\text { C-14 }\end{array}$ & $\begin{array}{c}\text { Number of } \\
\text { Samples }\end{array}$ & \%RSD \\
\hline $\begin{array}{c}\text { SB1B Glass (a) } \\
2000\end{array}$ & $\begin{array}{c}\text { Dried, Crushed } \\
\text { Glass }\end{array}$ & $<1.7 \mathrm{E}-09$ & 2 & $68(\mathrm{~b})$ \\
\hline $\begin{array}{c}\text { SB1B Slurry(c) } \\
1999\end{array}$ & $\begin{array}{c}\text { Dried Sludge } \\
\text { Slurry }\end{array}$ & $9.9 \mathrm{E}-08$ & 3 & $57(\mathrm{~d})$ \\
\hline
\end{tabular}

(a) See Reference [33]

(b) Based on dissolution of two glass samples and two standards.

(c) See Reference [4]

(d) Precision of the average result based on dissolution of three slurry samples.

\subsection{Calculation of the Waste Dilution Factor for SB1B}

The waste dilution factor (WDF) is the factor by which the concentration of an element or radionuclide in the HLW is diluted in the DWPF process by the addition of the nonradioactive glass forming frit to the sludge slurry being processed. This assumes that losses to other streams (liquid or vapor) during processing are negligible. The equation for calculating the WDF is:

$$
\mathrm{WDF}_{\mathrm{i}}=\mathrm{C}_{\mathrm{i}} / \mathrm{C}_{\text {gli }}
$$

Where $W_{D F}$ is the waste dilution factor for radionuclide or element $\mathrm{i}, \mathrm{C}_{\mathrm{i}}$ is the concentration of the radionuclide or element $\mathrm{i}$ in the dried sludge slurry, and $\mathrm{C}_{\mathrm{gli}}$ is the concentration of the radionuclide or element $\mathrm{i}$ in the glass. This factor can be used to predict the concentration of a radionuclide in the glass if its concentration has been measured in the dried sludge.

Values for the WDF were calculated based on the major nonradioactive elements in the waste that are not present in significant quantities in the frit. The best elements to use are $\mathrm{Fe}, \mathrm{Al}$, Ca, and $\mathrm{Mn}$. Table 5-2 gives the concentrations of these in the glass and in the dried sludge slurry and the calculated values for the WDF.

Table 5-2 Concentrations (Wt\%) of Major Nonradioactive Elements Specific to the Waste in S01142 Glass Along With Concentrations Determined in the Dried Sludge Slurry and the Calculated Waste Dilution Factor (WDF)

\begin{tabular}{|c|c|c|c||}
\hline Element & $\begin{array}{c}\text { Concentration } \\
\text { in Glass(a) }\end{array}$ & $\begin{array}{c}\text { Conc. In Dried } \\
\text { Sludge Slurry(b) }\end{array}$ & $\begin{array}{c}\text { Waste Dilution } \\
\text { Factor(c) }\end{array}$ \\
\hline $\mathrm{Al}$ & 2.8 & 7.7 & 2.7 \\
\hline $\mathrm{Fe}$ & 7.3 & 21. & 2.9 \\
\hline $\mathrm{Ca}$ & 0.99 & 2.2 & 2.2 \\
\hline $\mathrm{Mn}$ & 1.4 & 3.3 & 2.4 \\
\hline
\end{tabular}

(a) Values published in Reference 32.

(b) Values published in Reference 4.

(c) Waste Dilution Factor $=$ Conc. in dried sludge slurry/Conc. in glass 
The average WDF calculated from these elements is 2.6 with a standard deviation of 0.3 . This means that the elements in the dried sludge slurry were diluted by a factor of 2.6 just by the addition of the glass forming frit. With this factor the predicted concentration of C-14 presuming none is lost in the DWPF processing can be calculated.

\subsection{Prediction of Carbon-14 Concentration in Glass and the Fraction Lost in DWPF Processing}

The concentration of ${ }^{14} \mathrm{C}$ in the glass can be predicted using the average WDF and assuming that none of the ${ }^{14} \mathrm{C}$ is lost during DWPF processing. The predicted concentration is the measured concentration of ${ }^{14} \mathrm{C}$ in the dried sludge slurry divided by the average WDF. In this case the predicted concentration of ${ }^{14} \mathrm{C}$ in the glass is 3.8E-08 weight percent $(9.9 \mathrm{E}-08 / 2.6=3.8 \mathrm{E}-08)$. Based on the average concentration measured in the glass, the ${ }^{14} \mathrm{C}$ concentration, is less than $4 \%$ of the predicted $[(100)(<1.7 \mathrm{E}-09 / 3.8 \mathrm{E}-08)]$. This indicates that at least $96 \%$ of the ${ }^{14} \mathrm{C}$ did not get immobilized in the glass and was lost in the DWPF processing. Since $<4 \%$ of the $\mathrm{C}-14$ in the sludge did not get immobilized into the glass, the Curie content of the sludge is lowered by at least $96 \%$ to ascertain if ${ }^{14} \mathrm{C}$ is reportable by the WCP. When this is done, the Curie content of ${ }^{14} \mathrm{C}$ in the sludge at year 3115 is lowered to $<0.0018 \%$ which is much lower the than limit of $0.01 \%$ required by the DWPF WCP.[2] 


\subsection{CONCLUSIONS}

Based on the above analysis, we conclude that any ${ }^{14} \mathrm{C}$ that is present in the SRS HLW sent to the DWPF is lost to the atmosphere during processing in the DWPF and is not a reportable radionuclide in the glass. Consequently, measuring ${ }^{14} \mathrm{C}$ in the $\mathrm{HLW}$ is not required for repository acceptance of the glass.

The main soluble and insoluble salts of ${ }^{14} \mathrm{C}$ in the waste are carbonates, formates, and oxalates. Based on possible forms of ${ }^{14} \mathrm{C}$ in the cladding for the SRS fuels and targets, traces of cyanide or granular carbon species may be present. Also the analysis presented in Appendix A indicates that small amounts of degraded ion exchange resins or organic extractants may be present. All these species will be volatilized during DWPF processing. Carbonates and cyanides will be volatilized during SRAT and SME processing. Should any waste component containing ${ }^{14} \mathrm{C}$ such as, oxalate, and formate survive feed preparation in the DWPF and remain in the feed to the DWPF melter, the high temperatures during glass production will effectively "burn" these compounds to $\mathrm{CO}$ and $\mathrm{CO}_{2}$.

\subsection{ACKNOWLEDGEMENTS}

The authors acknowledge many scientific colleagues for lengthy discussions concerning the production of ${ }^{14} \mathrm{C}$ in the SRS reactors, its fate in the SRP/SRS processing steps, and in the DWPF processing steps. We are especially grateful to Dr. Harold Peacock of the Materials Application and Process Technology Section of SRNL and Dr. Frank Moore of the Analytical Development Section of SRNL. 


\subsection{REFERENCES}

1. Office of Environmental Restoration and Waste Management, Waste Acceptance Product Specifications for Vitrified High-Level Waste Form, USDOE Document DOE/EM-0093, Rev. 2, Savannah River Site, Aiken, SC 29808 (1996).

2. Westinghouse Savannah River Company, DWPF Waste Form Compliance Plan (U), WSRC-IM-91116-0, Rev.7, Savannah River Site, Aiken, SC 29808 (2003).

3. Bibler, N. E. and Hodoh, O. B., Calculating Waste Acceptance Radionuclides in DWPF Tank 51 Sludge Only Glass, WSRC-TR-95-0487, Rev.0, Savannah River Site, Aiken, SC 29808 (1996).

4. Fellinger, T. L., Bibler, N. E., and Harbour, J., R., Characterization of and Waste Acceptance Radionuclides to be Reported for DWPF Macro Batch 2 (ESP 215-ESP 221), WSRC-RP-9900436,Rev 1, Savannah River Site, Aiken, SC 29808 (2004).

5. Bibler, N. E., DiPrete, D. P., and Harbour, J. R., Determination of Reportable Radionuclides for DWPF Sludge Batch 2 (Macro Batch 3), WSRC-TR-2002-00256, Savannah River Site, Aiken, SC 29808 (2002).

6. Parrington, J. R., et al., Chart of the Nuclides and Isotopes, 15th Edition, GE Nuclear Energy, San Jose, CA (1996).

7. Fowler, J. R., and Coleman, C. J., Carbon-14 in Sludge, DPST-83-2001, Savannah River Laboratory, Aiken, SC 29808 (1983).

8. Hyder, M. L., Waste Acceptance Radionuclides to be Reported in Tank 51 Sludge Only Glass, WSRC-TR-95-00485, Savannah River Site, Aiken, SC 29808 (1995).

9. DiPrete, D. P., Personal Communication, Analytical Development Section, Savannah River National Laboratory, Aiken, SC, 29808, (2001).

10. DiPrete, D.P. "Results - C-14 Analyses on High Level Caves Sludge (U), SRT-ADS-99-1110, Savannah River Site, Aiken, SC 29808 (1999).

11. Martino, C. J., Wilmarth, W. R., Diprete, D. P., and Diprete, C. C., Tank 41H Dissolved Saltcake Sample (HTF-E-03-91 - 92), Saltstone Waste Acceptance Criteria Analysis, WSRC-TR-2003-038, Rev. 1, Savannah River Site, Aiken, SC 29808 (2003).

12. Hayes, D. W., and MacMurdo, K. W., “Carbon-14 Production by the Nuclear Industry,” Health Physics” Vol. 32, pp. 215-219 (1977).

13. Andreev, V. M, Nedopekin, V. G. and Rogov, V. I., “Sov. J. nucl. Phys.” Vol. 8, p. 14 (1969).

14. Willard, J. E., “Chemical Effects of Nuclear Transformation”, in Annual Review of Nuclear Science, Beckerley, J. G., Ed., p. 193, Annual Reviews Inc., Ca, (1953).

15. Moller, P., Nix, J. R., Myers, W. D., and Swiatecki, W. J., "Nuclear Ground State Masses and Deformation,” Atomic Data Nuclear Data Tables 59, pp. 185-381 (1995). 
16. Yankwich, P. E., Rollefson, G. K., and Norris, T. H., "Chemical Form Assumed by ${ }^{14} \mathrm{C}$ Produced by Neutron Irradiation of Nitrogenous Substances,” Journal of Chemical Physics Vol. 14, p. 131 (1946).

17. Peacock, H. B., Personal Communication, Materials Application and Process Technology Section, Savannah River National Laboratory, Aiken, SC, 29808, (2004). Discussions with Dr. Peacock were very helpful concerning the methods of fabrication of SRS reactor fuel ands targets. For more information on Dr. Peacock see Reference 5 of Appendix A.

18. Simpkins, A. A., Radionuclides in the Savannah River Site Environment, WSRC-MS-99-00667, Savannah River Site, Aiken, SC 29808 (1999).

19. Kleinberg, J., Argersinger, Jr., W. J., and Griswold, E., Inorganic Chemistry, p. 352,D. C. Heath and Company Boston, (1960), pp. 350-357, 617.

20. Patel, P. M., Personal Communication, Chemical Processing Engineering, Savannah River Site, Aiken, SC 29808 (2004).

21. Fellinger, T. L., Pareizs, J. M., Bibler, N. E., Cozzi, A. D. and Crawford, C. L., Confirmation Run of the DWPF SRAT Cycle Using Sludge-Only Flowsheet with Tank 40 Radioactive Sludge and Frit 200 in the Shielded Cells Facility, WSRC-TR-2002-00076, Savannah River Site, Aiken, SC 29808, (2002).

22. Kragten, J., Atlas of Metal-Ligand Equilibria in Aqueous Solution, pp. 70, 104, 626, Halsted Press, a division of John Wiley \& Sons, New York, (1978).

23. Hem, J. D., Study and Interpretation of the Chemical Characteristics of Natural Water, 3rd ed., p. 107, U. S. Geological Survey Water-Supply Paper 2254, U. S. Government Printing Office, Alexandria, VA (1986).

24. Kolhtoff, I. M. and Sandell, E. B., Textbook of Quantitative Inorganic Analysis, 3rd ed., p. 533, The Macmillan Co., New York (1978).

25. Fellinger, T. L., Pareizs, J. M., Bibler, N. E., Cozzi, A. D. and Crawford, C. L., Confirmation Run of the DWPF SME Cycle Using Sludge-Only Flowsheet with Tank 40 Radioactive Sludge and Frit 200 in the Shielded Cells Facility, WSRC-TR-2002-00096, Savannah River Site, Aiken, SC 29808 (2002).

26. Ray, J. W., Culbertson, B. H., Marra, S. L., and Plodinec, M. J., DWPF Glass Product Control Program, WSRC-IM-91-116-6, Rev. 5, Savannah River Site, Aiken, SC 29808 (2004). 
27. Choi, A. S., Prediction of Melter Off-Gas Explosiveness, WSRC-TR-1990-00346, Savannah River Site, Aiken, SC 29808 (1992).

28. Jantzen, C. M., et al.,Electron Equivalents Model for Controlling Reduction-Oxidation Equilibrium during High Level Waste Vitrification, WSRC-TR-2003-00126, Rev. 0, Savannah River Site, Aiken, SC 29808 (2003).

29. Norton Jones, W. General Chemistry, pp. 629-630; 493-494, 587-604 The Blakiston Company, Inc. New York (1954).

30. Cotton, F. A. and Wilkinson. G., Advanced Inorganic Chemistry, 2nd ed., pp. 306-315, Interscience Publishers, New York (1966).

31. Handbook of Chemistry and Physics, 22nd ed., p. 942, Chemical Rubber Publishing Co., Cleveland, Ohio, (1937).

32. Fellinger, T. L., and Bibler, N. E., Results of the Chemical Composition and the Product Consistency Test for the DWPF Macro Batch 2 Glass Pour Stream Sample Taken During the Pouring of Canister S01142, WSRC-RP-2000-00281, Rev. 0, Savannah River Site, Aiken, SC 29808 March, 2000.

33. Bibler, N. E., and Fellinger, T. L., Results of Radionuclide Composition for DWPF Macro Batch 2 Glass Pour Stream Sample Taken During the Pouring of Canister S01142, Rev.1, WSRC-RP-200000418, Rev. 1, Savannah River Site, Aiken, SC 29808 March, 2004.

34. Coleman, C. J., Acid Dissolution of Glass and Sludge for Elemental Analysis,” L16.1, ADS-2227, Rev. 6, Savannah River Site, Aiken, SC 29808 (1998). 
APPENDIX A

Source of ${ }^{14} \mathrm{C}$ in SRS Radioactive Wastes - JKLW-LET-112904

Letter from John R. Fowler

JKLW Enterprises, Inc.

849 Magnolia St., SE

Aiken, SC 29801 
JKLW Enterprises, Inc. 849 Magnolia St. SE Aiken, SC, SC 29801-4907

\section{JKLW-LET-112904}

November 29, 2004

\section{To: Ned Bibler \\ Savannah River National Laboratory Building 773-A}

\section{From: John R. Fowler}

\section{Source of ${ }^{14} \mathrm{C}$ into SRS Radioactive Wastes}

\subsection{Summary and Conclusions}

Potential sources and the chemistry of ${ }^{14} \mathrm{C}$ species during irradiation and subsequent processing at the SRS are summarized in this report. During irradiation, ${ }^{14} \mathrm{C}^{+4}$ ions (free $\mathrm{C}$ atoms stripped of valence electrons) from neutron interactions with ${ }^{13} \mathrm{C},{ }^{14} \mathrm{~N}$ and ${ }^{17} \mathrm{O}$ were formed. Traces of lubricants used in target/fuel fabrication and $\mathrm{CO}_{2}$ in air were the only readily identifiable sources of ${ }^{13} \mathrm{C}$ during irradiation in SRS reactors. Traces of metal nitrates from nitric acid etches used in plating and canning of uranium slugs, traces of nitrogen in air, AlN impurities in $\mathrm{Al}$ used as cladding and nitric acid used to adjust the $\mathrm{pH}$ of moderator were identified as possible sources of ${ }^{14} \mathrm{~N}$ during irradiation. Thin films of metal oxides on all metal surfaces exposed to air during fuel fabrication and moderator were possible sources of ${ }^{17} \mathrm{O}$.

During irradiation, ${ }^{14} \mathrm{C}^{+4}$ atoms were deposited into the bulk metal matrices of fuels and targets (Al, $\mathrm{U}$ or $\mathrm{Ni}$ metals with thin oxide coatings on each metal component or alloy); into the moderator $\left(\mathrm{D}_{2} \mathrm{O}\right)$; into trapped air within canned targets or at the top of the reactor vessel; and into reactor components (e.g., stainless steel reactor vessel and the aluminum tubes that hold the fuels and target elements). Chemical interactions with the more electropositive metals in the immediate vicinity of the deposited carbon ion within the bulk metal matrix of fuels and targets formed ${ }^{14} \mathrm{C}^{4-}$. Chemical interactions within slightly acidic

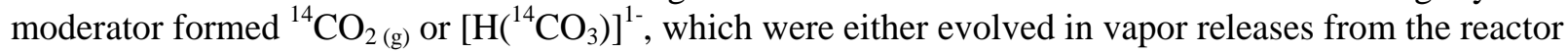
stacks or removed by ion exchange resins used to maintain the quality of the moderator (Ref. 6). Carbonate, carbon dioxide or carbon monoxide may also have formed from chemical interaction inside the fuel and targets during irradiation, if a ${ }^{14} \mathrm{C}^{+4}$ ion deposited in a metal oxide layer or near traces of metal nitrates that may have been present at metal-metal interfaces within the fuels or targets. If deposited ${ }^{14} \mathrm{C}^{+4}$ interacted with air trapped inside a fuel or target element, then carbon monoxide, carbon dioxide or cyanide may have formed through chemical interaction with oxygen or nitrogen gas.

Carbon dioxide, soluble and insoluble carbonate compounds and possibly oxalate, formate and cyanide compounds are the most likely species generated from processing fuels and targets containing ${ }^{14} \mathrm{C}$ species formed during irradiation. Although "metal carbide" may have formed in the fuels and targets, they would chemically react during nitric acid dissolution to produce metal nitrates and carbon dioxide. Caustic dissolution used to dissolve aluminum cladding would generate sodium aluminate and carbonate salts. Various transfers from RBOF and from the reactor areas are other potential sources of ${ }^{14} \mathrm{C}$ which may have been sent to a waste tank. These transfers were related to maintaining the quality of the heavy water moderator, the efficiency of the reactor heat exchangers and the replacement of a failed reactor sand filter. Unless experimental evidence is obtained to show otherwise, trace quantities of formate, oxalate and cyanide salts cannot be eliminated as possible waste components "enriched" in ${ }^{14} \mathrm{C}$, especially from waste streams sent directly from the reactor areas or RBOF. 
The chemistry of these possible species is discussed throughout this report. Based on known chemical properties, most of the ${ }^{14} \mathrm{C}$ retained in fuels and targets was released as $\mathrm{CO}_{(\mathrm{g})}$ or $\mathrm{CO}_{2}$ (g) from the canyon stacks in $\mathrm{F}$ Area and $\mathrm{H}$ Area during fuel dissolution. However, caustic dissolution of aluminum cladding during Purex processing in both F and H Area Separations retained carbonate in the caustic waste solution. Sodium carbonate and insoluble carbonates have been shown to be primary sources of ${ }^{14} \mathrm{C}$ retained in waste transferred to the Tank Farms from Separations. Elemental carbon, carbonate salts, oxalate salts, formate salts and cyanide salts are the only plausible carbon compounds "enriched in ${ }^{14} \mathrm{C}$ " that could have been transferred to SRS waste tanks, based on a review of processes used at the SRS.

Treatment with nitric acid and formic acid during feed preparation in the SRAT removes carbonate from the waste through reactions that convert carbonate salts to formate and/or nitrate salts. $\mathrm{CO}_{2 \text { (g) }}$ is formed in these reactions and purged from the waste slurry to the Process Vessel Vent System (PVVS) as a component of the off-gases and air purges from the SRAT and SMECT. Although carbonates are effectively eliminated from the waste when melter feed is prepared in the DWPF, carbonate reactions in the melter may still occur because oxalate salts may not completely decompose in the SRAT. Oxalate salts can form carbonate salts in the melter if they simply decompose instead of reacting with another waste component.

Based on melter operating conditions, the known chemistry and physical properties of these components and their decomposition products predict all components containing carbon will either decompose or be oxidized by oxygen or other waste components before reaching the molten glass. If a carbonate is formed from a reaction, it may persist as a solid until it reaches the surface of molten glass where it then decomposes at the melt temperature. In these reactions, $\mathrm{CO}_{(\mathrm{g})}$ and/or $\mathrm{CO}_{2(\mathrm{~g})}$ are evolved to the Melter Off-Gas (MOG) system, effectively removing carbon containing compounds from the melter before they can be incorporated into the molten glass.

Except for trace quantities of $\mathrm{CO}_{2}$ and possibly $\mathrm{HCN}$ that may be retained in various aqueous condensate streams, ${ }^{14} \mathrm{C}$ sent to the DWPF is released directly to the environment as $\mathrm{CO}_{2}$ (g) through the S-Area Stack. The trace quantities of ${ }^{14} \mathrm{C}$ retained in condensates will eventually be sent to the Tank Farm and disposed as a component of saltstone, along with the ${ }^{14} \mathrm{C}$ associated with salt waste stored in the Tank Farms.

\subsection{Fuel and Target Fabrication for SRS Reactors}

Fuels and targets used in the SRS production reactors were clad in aluminum to protect metals such as uranium or plutonium from corrosion by the heavy water moderator during irradiation. The cladding also helped to prevent escape of fission products from the fuel and targets. The canning technology used in the 1950's has been refined and extended over the years but the basic concept of using a sealed can to contain fuel or fertile material was used throughout the operational life of the SRS reactors. Fuel forms have evolved from solid metal slugs of natural uranium to extruded fuel tubes containing enriched uranium. (Ref. 1, 2, 3, 4)

After fabrication, fuels and targets were irradiated in the SRS reactors to generate the desired products within the fuel and target assemblies. The irradiated materials were then transferred to either $\mathrm{F}$ Area or $\mathrm{H}$ Area where they were processed to separate and purify the desired products. Fabrication techniques used at the SRS are briefly described below. 


\subsection{Canning Uranium Slugs}

Natural U slugs contained in sealed aluminum cans were used as fuels in the 1950's to produce plutonium. In the initial fuel production, a slug was etched with nitric acid before inserting it into a heated aluminum can under the surface of a molten Al-Si bath. After placing a slug in a can, an aluminum end cap was placed on the exposed end of the slug and the seam between the cap and can was sealed by welding. A thin Al-Si braze layer provided a heat transfer bond between the slug and the can. (Ref. 1, 2)

In 1959, the Al-Si braze layer was replaced with an electroplated nickel layer and hot-die sizing was used to improve the heat transfer bond between the plated slug of natural $\mathrm{U}$ and the $\mathrm{Al}$ can. In this process, the U slug was first etched with nitric acid and rinsed with water to provide a clean surface for electroplating a thin layer of nickel. The Ni-plated slug was etched again in nitric acid, rinsed with water, air-dried and then inserted into an aluminum can heated to $500^{\circ} \mathrm{C}$. After placing an end cap on the exposed end of the slug, the unsealed can containing the slug was swaged through a heated die while simultaneously applying pressure to both ends of the can. (Ref. 1, 5)

Before welding the seam between the cap and can, the weld area was cleaned to remove lubricants used in hot-die sizing. From 1955 to 1969 and from 1973 to 1976, cans were etched with nitric acid and rinsed with water to remove die lubricants. From 1969 to 1973, shell blasting was used, but it was abandoned in 1973 because of a high rate of weld failures. Nitric acid etching was resumed until a mechanical grinder was successfully demonstrated in 1976. (Ref. 1, 5) After cleaning, the seam between the cap and can was welded to seal the can. These techniques for aluminum-cladding U slugs (and other special targets) were used until fuel and target production ceased in the early 1990's.

Because nitric acid was used extensively in the 300-M slug canning process, trace levels of nitrate salts of $\mathrm{U}, \mathrm{Ni}$ and $\mathrm{Al}$ were probably retained on the surface of the slugs when they were sealed in the aluminum cans. Small quantities of air may also have been retained, especially in the areas at the junction between the sides and ends of the cans. Any trace metal nitrates retained on the exterior aluminum surfaces when nitric acid was used to clean the weld area before welding were subsequently removed when the canned slugs were rinsed and then autoclaved after welding. However, metal nitrates or trapped air (containing $\mathrm{N}_{2}$ ) in the interior of the cans were retained. These compounds containing nitrogen are likely a significant source for the generation of ${ }^{14} \mathrm{C}$ within the fuel elements during irradiation, although oxides of metals on interior surfaces may contribute a minor amount.

\subsection{Enriched Uranium Fuel Tubes}

As noted above, early reactor operations at the SRS used fuel elements consisting of solid metal slugs of natural $U$ contained in sealed aluminum cans. Hollow slugs of natural $U$ sealed in hollow aluminum cans were introduced in the late 1950's to increase the surface area exposed to the moderator, thus improving heat transfer. Heat transfer for fuel assemblies was further improved in the early 1960's by converting to nested assemblies of large-diameter, thin-walled tubular fuel elements containing enriched uranium instead of natural uranium. These tubes had cores of enriched U/Al alloys covered with a thin layer of aluminum cladding on the interior and exterior surfaces of the tubes. (Ref. 2)

To fabricate the tubes, billets of U/Al alloy surrounded by billets of pure aluminum were co-extruded to yield fuel tubes containing a core of enriched U/Al alloy encapsulated by exterior cladding layers of aluminum. (Ref. 2) At the same time that extruded tubes were adopted for reactor operations, canned slugs of natural uranium were replaced with canned slugs of depleted uranium that functioned as targets for the production of ${ }^{239} \mathrm{Pu}$. These changes improved the efficiency of ${ }^{239} \mathrm{Pu}$ production while enabling the use of other target materials to produce other useful isotopes. (Ref. 2, 3, 4) Co-extrusion was used to produce fuel tubes until the early 1990’s. 


\subsection{Targets for Productions of Other Isotopes}

Over the years of SRS operations, several materials (Ref. 4) have been used as targets to produce other isotopes:

- $\mathrm{Li} / \mathrm{Al}$ alloys to produce tritium

- $\quad{ }^{232} \mathrm{ThO}_{2}$ targets to produce ${ }^{233} \mathrm{~Pa}$ and ${ }^{233} \mathrm{U}$

- ${ }^{237} \mathrm{NpO}_{2}$ targets to produce ${ }^{238} \mathrm{Pu}$

- $\mathrm{PuO}_{2}$ targets to produce $\mathrm{Cm}$ and $\mathrm{Cf}$

- $\quad{ }^{59} \mathrm{Co}$ targets to produce ${ }^{60} \mathrm{Co}$

\subsection{Off-Site Fuels}

In addition to materials fabricated and processed at the SRS to support defense programs, several enriched uranium fuel assemblies fabricated elsewhere and used in off-site reactors have been processed in the $\mathrm{H}$ Area Canyon. These irradiated fuels were processed to recover enriched uranium loaned by the Department of Energy for various tests related to research and development of advanced reactor and fuel designs. Several of these special campaigns demonstrated new processes for the recovery and reuse of fuels from commercial power reactors. Cladding (e.g., stainless steel, zircaloy) and/or fuel forms (e.g., U/Mo alloys, mixed oxide fuels) used in many of these fuel assemblies required the use of an electrolytic dissolver located in $\mathrm{H}$ Canyon to co-dissolve the cladding and fuel in a nitric acid solution before using variations of the HM process to recover and purify the desired products. Radioactive waste from processing these fuels was sent to $\mathrm{H}$ Area waste tanks where it was combined with wastes generated from processing SRS fuels and targets.

\subsection{Production of ${ }^{14} \mathrm{C}$ in Savannah River Site (SRS) Reactors}

To identify possible chemical species containing ${ }^{14} \mathrm{C}$ in various SRS wastes, the method of generation and the possible chemical forms of species containing potential ${ }^{14} \mathrm{C}$ precursors must be considered. Formation of ${ }^{14} \mathrm{C}$ in SRS fuels, targets and waste can come from transmutation of ${ }^{13} \mathrm{C}$ through absorption of a neutron, transmutation of ${ }^{14} \mathrm{~N}$ through an (n, p) reaction and transmutation of ${ }^{17} \mathrm{O}$ through an $(n, \alpha)$ reaction. Using elemental forms for the precursors, these nuclear reactions may be represented by these three nuclear reactions, with corresponding electron transfer reactions included to maintain a net charge balance:

$$
\begin{aligned}
& { }^{13} \mathrm{C}+{ }^{1} \mathrm{n} \rightarrow\left[{ }^{14} \mathrm{C}\right]^{*} \rightarrow{ }^{14} \mathrm{C}+\gamma \\
& { }^{14} \mathrm{~N}+{ }^{1} \mathrm{n} \rightarrow\left[{ }^{15} \mathrm{~N}\right]^{*} \rightarrow\left[{ }^{14} \mathrm{C}^{1-}\right]^{*}+{ }^{1} \mathrm{p}^{1+} \rightarrow{ }^{14} \mathrm{C}+{ }^{1} \mathrm{H} \\
& { }^{17} \mathrm{O}+{ }^{1} \mathrm{n} \rightarrow\left[{ }^{18} \mathrm{O}\right]^{*} \rightarrow\left[{ }^{14} \mathrm{C}^{2-}\right]^{*}+{ }^{4} \alpha^{2+} \rightarrow{ }^{14} \mathrm{C}+{ }^{4} \mathrm{He}
\end{aligned}
$$

Although the overall charge balance of the nuclear reactions are preserved in the above reactions, they do not reflect the actual charge or chemical reactivity of the carbon species produced initially, nor do they address the chemical environment that could surround these species when they are produced. For the SRS reactors, the transmutation of ${ }^{13} \mathrm{C}$ to ${ }^{14} \mathrm{C}$ is negligible within the fuels and targets, compared to the reactions involving ${ }^{14} \mathrm{~N}$ and ${ }^{17} \mathrm{O}$. Except for metal-oxide targets used in special irradiations, nitrogencontaining species dominate as precursors for ${ }^{14} \mathrm{C}$ within fuels and targets used at the SRS. (Ref. 6) Because the moderator is in direct contact with the external aluminum surfaces of all targets and fuel tubes during irradiation, a small fraction of the (n, p) and $(n, \alpha)$ reactions that occur in the moderator can also deposit ${ }^{14} \mathrm{C}^{+4}$ ions directly in the metal matrix of the fuel and targets. Possible nitrogen- and oxygen- 
containing species that could be present in fuels, targets and moderator used in the reactor must be considered to identify possible chemical forms of ${ }^{14} \mathrm{C}$ species that could be generated during reactor operations at SRS.

\subsection{Possible $\mathbf{C}, \mathbf{N}$ and $\mathbf{O}$ Species in Fuels and Targets before Irradiation}

As mentioned above, nitric acid was used extensively in the 300-M slug canning process and trace levels of nitrate salts of $\mathrm{U}, \mathrm{Ni}$ and $\mathrm{Al}$ were probably retained on the surface of the plated uranium slugs when they were sealed in the aluminum cans. Residues of $\mathrm{UO}_{2}\left(\mathrm{NO}_{3}\right)_{2}, \mathrm{Ni}\left(\mathrm{NO}_{3}\right)_{2}$ and $\mathrm{Al}\left(\mathrm{NO}_{3}\right)_{3}$ were likely present at the highest concentration of all the possible ${ }^{14} \mathrm{C}$ precursors in canned slugs of either natural or depleted U.

Based on vendor specifications for materials used to fabricate natural and enriched uranium fuels and depleted uranium targets, only trace levels of compounds containing carbon, nitrogen and/or oxygen were present in the bulk metals obtained from vendors. (Ref. 5) However, all metal surfaces exposed to air prior to canning or extrusion would be covered with a thin layer of the oxide of any underlying metal.

Nitric acid was not used to etch billets of alloys or aluminum that were used to extrude fuel tubes and nitrate impurities. Extrusion techniques used to fabricate fuel tubes containing enriched uranium are unlikely to introduce additional impurities that could lead to significant production of ${ }^{14} \mathrm{C}$ during irradiation, although longer irradiation times used for the enriched uranium fuel assemblies (180 days) than for the depleted uranium targets (30 days) would increase the quantity of ${ }^{14} \mathrm{C}$ produced in the fuel tubes, especially from transmutation of ${ }^{17} \mathrm{O}$. The species present in both fuels and targets that can lead to the formation of ${ }^{14} \mathrm{C}$ are:

- $\mathrm{Al}_{2} \mathrm{O}_{3}, \mathrm{NiO}$ and $\mathrm{UO}_{2}$ formed on bulk metal surfaces during fabrication of fuels and targets;

- Traces of $\mathrm{Al}_{2} \mathrm{O}_{3}, \mathrm{AlN}$ and $\mathrm{UO}_{2}$ dispersed in the bulk metals that were retained when the metals were produced;

- Traces of $\mathrm{N}_{2}$ and $\mathrm{O}_{2}$ dissolved in the bulk metals or inadvertently trapped during fabrication of fuel and target elements;

- $\quad$ The oxide ions in $\mathrm{MO}_{2}$ targets $(\mathrm{M}=\mathrm{Th}, \mathrm{Pu}, \mathrm{Np}, \mathrm{Cm})$ used for special irradiations.

- In canned slugs only, traces of nitrate salts may also be present.

None of these impurities were ever measured in the metals, but all were expected to be present at very low concentrations from normal metal processing techniques used to fabricate metals used in fuels and targets. (Ref. 5) 
The recoil energy of the ${ }^{14} \mathrm{C}$ in the nuclear reactions is sufficient to break existing chemical bonds, and the displaced ${ }^{14} \mathrm{C}^{4+}$ will interact in the matrix where it is deposited to gain electrons and form a chemically stable compound. If ionized carbon atoms are deposited within bulk metals used in targets and fuels (i.e., $\mathrm{Ni}, \mathrm{U}, \mathrm{Al}$ ), then either free carbon atoms or carbides of the metals will form. If it deposits in a metal oxide layer or the moderator then $\mathrm{CO}, \mathrm{CO}_{2}$ or carbonate will form. If it deposits in a trapped air pocket within a target then $\mathrm{CO}, \mathrm{CO}_{2}$ or $\mathrm{CN}^{1-}$ will form through interaction with oxygen and/or nitrogen. Residual ions left behind when the carbon atom is displaced from a stable chemical compound will also interact chemically to form stable species (oxides or nitrides). The resultant ${ }^{14} \mathrm{C}$ chemical species retained within the fuel or targets react to generate various products during subsequent dissolution in either caustic or acid. The chemistry during dissolution is discussed below in the context of conditions used to dissolve the fuels and targets.

\subsection{Separations Processing of Fuels and Targets}

The Purex process is used to separate Pu and $\mathrm{U}$ from cladding and fission products, followed by a second process cycle to separate Pu from U. This process has been used exclusively by F-Area Separations to recover Pu and U from irradiated fuels and targets. It was also used by H-Area Separations from 1955 until 1962.

In 1962, the HM Process, which co-dissolves $\mathrm{Al}$ and $\mathrm{U}$ fuels, was implemented in $\mathrm{H}$ Area to enable processing and recovery of enriched $U$ from tubular fuel elements that were adopted for reactor operations in the early 1960's. Co-dissolution is also used in H Area to dissolve targets to enable products from special irradiations to be recovered (e.g., Th, ${ }^{233} \mathrm{~Pa},{ }^{237} \mathrm{~Np}, \mathrm{Am}, \mathrm{Cm},{ }^{238} \mathrm{Pu}$ ).

The HM Process is used to separate enriched U, Np and Pu from cladding and fission products, followed by additional cycles that separate and recover $U$ and $\mathrm{Np}$ while rejecting Pu to waste. An additional cycle can also be run to recover the $\mathrm{Pu}$, if desired from the aqueous waste stream generated in the second cycle. Other modifications enable the recovery of ${ }^{233} \mathrm{~Pa}$ or ${ }^{233} \mathrm{U}$ from ${ }^{232} \mathrm{Th}$.

\subsection{Purex Process}

A caustic dissolution is first completed to remove the aluminum cladding. After decanting the caustic dissolver solution and rinsing the undissolved slugs, the uranium (and nickel plating, if present) is then dissolved in a separate dissolution cycle using $\sim 8 \mathrm{M}$ nitric acid. The resulting acidic dissolver solution is then treated by a head-end strike and centrifuged to remove insoluble solids. The clarified solution (feed) is adjusted as needed and processed through solvent extraction. The first cycle of the Purex solvent extraction process separates Pu and $\mathrm{U}$ from cladding and fission products. The second process cycle separates Pu from U into separate aqueous solutions of their respective nitrate salts. (Ref. 7) The Purex process has been used in F Area since startup in the mid 1950's and in H Area from 1955 until 1962.

\subsubsection{Aluminum Cladding Dissolution}

In the Purex process, aluminum cladding on U slugs (natural or depleted) was chemically dissolved using a solution of $\mathrm{NaOH}$ at about $100{ }^{\circ} \mathrm{C}$, without dissolving the uranium core (with or without Ni plating). A $5 \%$ excess of $\mathrm{NaOH}$ was used to prevent the precipitation of aluminum hydroxide, based on the mass of $\mathrm{Al}$ to be dissolved. Sodium nitrate was also added to the solution to suppress the generation of hydrogen. (Ref. 7) In strong caustic solution, nitrate is reduced to ammonia as aluminum dissolves by providing a mild oxidant to interact with nascent hydrogen atoms as they are generated at the surface of aluminum (Ref. 11): 


$$
3 \mathrm{NaNO}_{3}+8 \mathrm{Al}+5 \mathrm{NaOH}+2 \mathrm{H}_{2} \mathrm{O} \rightarrow 8 \mathrm{NaAlO}_{2}+3 \mathrm{NH}_{3}(\mathrm{~g})
$$

If AlN is present as an impurity in the cladding or is formed from interactions due to irradiation, it will also react to generate $\mathrm{NH}_{3}$ (Ref. 9, 10):

$$
\mathrm{AlN}+\mathrm{NaOH}+\mathrm{H}_{2} \mathrm{O} \rightarrow \mathrm{NaAlO}_{2}+\mathrm{NH}_{3}(\mathrm{~g})
$$

Ammonia, hydrogen and other non-condensable gases that may have formed during caustic dissolution of aluminum were released to the Vessel Vent System of the Separation canyons, and eventually to the general environment from the canyon stacks. Both carbon monoxide and carbon dioxide can react with caustic; most of these gases (if not all) were retained in the spent solution generated from aluminum decladding.

Any nickel or uranium species (carbonates, cyanides or carbides) that may have formed in the bulk metals are not readily soluble in caustic solution and do not release ${ }^{14} \mathrm{C}$ species into the caustic solution. Residual uranium or nickel nitrate salts that may be present would simply form insoluble hydroxides and sodium nitrate. $(9,10,11)$

After the aluminum dissolution was completed, the spent caustic decladding solution (called "coating waste") was transferred to another tank in the canyon. The uranium slugs were rinsed with water and the rinse was transferred and combined with the coating waste.

Liquid waste from B-Line operations was usually combined with the coating waste, adjusted as needed to meet the Tank Farm's Waste Acceptance Criteria, and then transferred to the designated "Fresh Low-Heat Waste Receipt Tank” in the tank farm. (Ref. 7)

B-Line waste contains soluble calcium salts (Ref. 7) that are generated from the reduction of Pu salts to metal. Calcium precipitates carbonate, fluoride or sulfate, all of which may be present in the combined waste stream. Other trace metals that may be present (e.g., $\mathrm{Ni}, \mathrm{Fe}, \mathrm{Pb}, \mathrm{Hg}, \mathrm{Mn}$ ) may precipitate cyanide, if it is in the combined waste stream. (Ref. 9)

Possible species containing ${ }^{14} \mathrm{C}$ in the blend of coating waste and B-Line waste thus could include soluble sodium carbonate, soluble sodium cyanide, insoluble calcium carbonate and insoluble metal cyanides. Various carbonates dominate as the most likely species containing ${ }^{14} \mathrm{C}$, since metal carbides that oxidize are the most likely source of ${ }^{14} \mathrm{C}$ in the fuels and targets. Cyanide, if present, likely also reacts to generate carbonates and ammonia, as discussed below.

If species containing ${ }^{14} \mathrm{C}$ are present in the cladding or on the inner surfaces of the can or plated slug, then they would react or dissolve during dissolution of the aluminum in caustic to yield soluble sodium salts or be evolved as gases from the dissolver. Specific reaction products would depend on the chemical form of ${ }^{14} \mathrm{C}$ and its reactivity when exposed to the caustic solution containing sodium nitrate (Ref. 9, 10, 11). Possible reactions species and their reactions are discussed below. 


\subsubsection{Chemistry of Possible ${ }^{14} \mathrm{C}$ Irradiation Products during Caustic Dissolution}

\section{Carbon Oxides}

If ${ }^{14} \mathrm{C}$ interacts with oxygen or an oxide within the cladding matrix as noted above, either ${ }^{14} \mathrm{CO}$ or ${ }^{14} \mathrm{CO}_{2}$ would be formed. ${ }^{14} \mathrm{CO}$ would either evolve as a component of the dissolver off gas or interact with caustic to yield sodium formate during caustic dissolution of aluminum cladding:

$$
{ }^{14} \mathrm{CO}_{(\mathrm{g})}+\mathrm{NaOH} \rightarrow \mathrm{Na}\left({ }^{14} \mathrm{COOH}\right)
$$

${ }^{14} \mathrm{CO}_{2}$ would react in the caustic dissolution to form sodium carbonate:

\section{Cyanide}

$$
{ }^{14} \mathrm{CO}_{2(\mathrm{~g})}+2 \mathrm{NaOH} \rightarrow \mathrm{Na}_{2}\left({ }^{14} \mathrm{CO}_{3}\right)
$$

If cyanide is present in the cladding matrix due to interaction with nitrogen, it should also be oxidized by the mildly oxidizing caustic/sodium nitrate mixture to yield sodium cyanate. Cyanate would then hydrolyze to yield carbonate and ammonia (evolved as a gas) in the alkaline media, as shown in the following reactions (Ref. 11):

$$
\begin{aligned}
& \left(\mathrm{M}^{\mathrm{n}+}\right)\left({ }^{14} \mathrm{CN}^{1-}\right)_{\mathrm{n}}+\mathrm{n} \mathrm{NaOH} \rightarrow \mathrm{n} \mathrm{Na}\left({ }^{14} \mathrm{CN}\right)+\mathrm{M}(\mathrm{OH})_{\mathrm{n}}+2 \mathrm{H}_{2} \mathrm{O} \\
& \mathrm{Na}\left({ }^{14} \mathrm{CN}\right)+\mathrm{NaNO}_{3} \rightarrow \mathrm{Na}\left(\mathrm{O}^{14} \mathrm{CN}\right)+\mathrm{NaNO}_{2} \\
& \mathrm{Na}\left(\mathrm{O}^{14} \mathrm{CN}\right)+\mathrm{NaOH}+\mathrm{H}_{2} \mathrm{O} \rightarrow \mathrm{Na}_{2}\left({ }^{14} \mathrm{CO}_{3}\right)+\mathrm{NH}_{3}(\mathrm{~g})
\end{aligned}
$$

\section{Carbides}

Chemically, an anionic form of $\mathrm{C}$ is the most likely form of ${ }^{14} \mathrm{C}$ within the irradiated fuel, targets and cladding. Two forms of aluminum carbide are known- $\mathrm{Al}_{4} \mathrm{C}_{3}$ containing $\mathrm{C}^{4-}$ and $\mathrm{Al}_{2}\left(\mathrm{C}_{2}\right)_{3}$ containing $\mathrm{C}_{2}{ }^{2-}$. These pure compounds react during aqueous dissolution to yield methane or acetylene according to the following equations (Ref. 9, 10):

$$
\begin{aligned}
& \mathrm{Al}_{4} \mathrm{C}_{3}+12 \mathrm{H}_{2} \mathrm{O} \rightarrow 4 \mathrm{Al}(\mathrm{OH})_{3}+3 \mathrm{CH}_{4}(\mathrm{~g}) \\
& \mathrm{Al}_{2}\left(\mathrm{C}_{2}\right)_{3}+6 \mathrm{H}_{2} \mathrm{O} \rightarrow 2 \mathrm{Al}(\mathrm{OH})_{3}+3 \mathrm{C}_{2} \mathrm{H}_{2}(\mathrm{~g})
\end{aligned}
$$

However, neither of the above carbides really represents the chemical environment surrounding a single ${ }^{14} \mathrm{C}$ atom deposited within an aluminum matrix (or any other metal matrix) during irradiation.

Furthermore, these reactions do not yield a chemical form that would be retained in the dissolver solution. An alternative reaction sequence to form anionic ${ }^{14} \mathrm{C}$ species is suggested that is consistent with ${ }^{14} \mathrm{C}$ being retained during caustic dissolution of aluminum.

During caustic dissolution used in the Purex process to declad uranium slugs, sodium nitrate is also added to the caustic solution to suppress hydrogen generation. The high chemical activity of aluminum should stabilize the electron-deficient carbon deposited from (n, p) reactions through covalent bonding with the 4 nearest aluminum neighbors, yielding an $\mathrm{Al}_{4}\left({ }^{14} \mathrm{C}\right)$ cluster with carbon at the center. The presence of sodium nitrate is also postulated to suppress the generation of methane, acetylene or other hydrocarbons that are generated when pure aluminum carbides react with water. (Alternatively, the dissolution releases the ${ }^{14} \mathrm{C}$ as elemental carbon which then reacts with sodium nitrate to yield $\mathrm{CO}$ or $\mathrm{CO}_{2}$, both of which react with caustic to yield formate or carbonate, respectively.) The net overall reaction for the conversion to carbonate based on this hypothesis is shown below: 


$$
2 \mathrm{Al}_{4}\left({ }^{14} \mathrm{C}\right)+8 \mathrm{NaOH}+4 \mathrm{NaNO}_{3}+2 \mathrm{H}_{2} \mathrm{O} \rightarrow 8 \mathrm{NaAlO}_{2}+2 \mathrm{Na}_{2}\left({ }^{14} \mathrm{CO}_{3}\right)+4 \mathrm{NH}_{3}(\mathrm{~g})
$$

Although unlikely, incomplete oxidation of the carbide during aluminum dissolution in caustic could also give rise to formate salts or oxalate salts, both of which would also remain in the caustic solution:

$$
\begin{aligned}
& 4 \mathrm{Al}_{4}\left({ }^{14} \mathrm{C}\right)+13 \mathrm{NaOH}+7 \mathrm{NaNO}_{3}+6 \mathrm{H}_{2} \mathrm{O} \rightarrow 16 \mathrm{NaAlO}_{2}+4 \mathrm{Na}\left(\mathrm{H}^{14} \mathrm{COO}\right)+7 \mathrm{NH}_{3}(\mathrm{~g}) \\
& 8 \mathrm{Al}_{4}\left({ }^{14} \mathrm{C}\right)+25 \mathrm{NaOH}+15 \mathrm{NaNO}_{3}+10 \mathrm{H}_{2} \mathrm{O} \rightarrow 32 \mathrm{NaAlO}_{2}+4 \mathrm{Na}_{2}\left[\left(\mathrm{O}_{2}{ }^{14} \mathrm{C}\right)-\left(\mathrm{CO}_{2}\right)\right\}+15 \mathrm{NH}_{3(\mathrm{~g})}
\end{aligned}
$$

These reaction sequences could be tested by irradiating aluminum tubes filled with a nitrogen atmosphere to generate ${ }^{14} \mathrm{C}$ in an aluminum matrix from transmutation of ${ }^{14} \mathrm{~N}$. Dissolutions in caustic with and without sodium nitrate would provide solutions to be tested for the presence of ${ }^{14} \mathrm{C}$, as well as helping to identify the specific chemical species containing ${ }^{14} \mathrm{C}$. Secondary information on the transmutation of ${ }^{27} \mathrm{Al}$ to ${ }^{28} \mathrm{Si}$ could also be obtained.

\subsubsection{Uranium Core Dissolution (Purex)}

Nitric acid is used to dissolve the uranium cores to provide feed solution for the solvent extraction process that removes fission products in a separate waste stream and separates $\mathrm{U}$ from $\mathrm{Pu}$. The oxidizing nature of nitrate suppresses the generation of hydrogen during core dissolution, just as it does when aluminum is dissolved in caustic.

Mixtures of hydrogen and hydrocarbons are normally observed when transition metal carbides, such as $\mathrm{Ni}_{3} \mathrm{C}$, are hydrolyzed in water or acidic solution ( $\mathrm{HX}=$ water or a non-oxidizing acid). Uranium carbide, such as $\mathrm{UC}_{2}$, dissolves in water or non-oxidizing acid to generate acetylene (Ref. 9, 10):

$$
\begin{aligned}
& \mathrm{HX}+\mathrm{Ni}_{3} \mathrm{C} \rightarrow \text { mixture of hydrogen, methane, other hydrocarbons }+\mathrm{Ni}(\mathrm{X})_{2} \\
& \mathrm{HX}+\mathrm{UC}_{2} \rightarrow \text { acetylene }
\end{aligned}
$$

$\mathrm{Ni}$ and $\mathrm{U}$ carbides would be formed when ${ }^{14} \mathrm{C}$ ions are deposited in the bulk metals from (n, p) reactions, but not in the atomic ratio for known carbides of these metals. Carbides formed through irradiation processes would readily dissolve when the bulk metals are dissolved in nitric acid, since the carbon atoms are widely separated. With strongly oxidizing nitric acid, hydrogen and hydrocarbons are suppressed during dissolution. $\mathrm{Ni}_{3}{ }^{14} \mathrm{C}$ from (n, p) reactions would readily dissolve with the bulk metal to yield ${ }^{14} \mathrm{CO}_{2}$ from nickel carbide, not methane or a mixture of hydrogen and hydrocarbons. In strong acid solution, any carbon dioxide formed is evolved as a component of the dissolver off-gas:

$$
10 \mathrm{HNO}_{3}+\mathrm{Ni}_{3}{ }^{14} \mathrm{C} \rightarrow 3 \mathrm{Ni}\left(\mathrm{NO}_{3}\right)_{2}+2 \mathrm{NO}_{2(\mathrm{~g})}+{ }^{14} \mathrm{CO}_{2(\mathrm{~g})}+\mathrm{NH}_{4} \mathrm{NO}_{3}+3 \mathrm{H}_{2} \mathrm{O}
$$

During acid dissolution of $U$, the nitric acid would also readily react with $U^{14} \mathrm{C}$ from (n, p) reactions contained in the metal matrix to yield ${ }^{14} \mathrm{CO}_{2}$ as an off-gas component from the dissolver:

$$
6 \mathrm{HNO}_{3}+\mathrm{U}^{14} \mathrm{C} \rightarrow \mathrm{UO}_{2}\left(\mathrm{NO}_{3}\right)_{2}+2 \mathrm{NO}_{2(\mathrm{~g})}+{ }^{14} \mathrm{CO}_{2(\mathrm{~g})}+\mathrm{NH}_{4} \mathrm{NO}_{3}+\mathrm{H}_{2} \mathrm{O}
$$


If carbonates and/or cyanides containing ${ }^{14} \mathrm{C}$ are present in the $\mathrm{U}$ and $\mathrm{Ni}$ metal matrices, off-gases from the dissolver during nitric acid dissolution would contain volatile ${ }^{14} \mathrm{CO}_{2}$ and $\mathrm{H}^{14} \mathrm{CN}$, in addition to the various oxides of nitrogen that are generated during dissolution, effectively eliminating ${ }^{14} \mathrm{C}$ species from the acidic solution:

$$
\begin{aligned}
& 2 \mathrm{HNO}_{3}+{ }^{14} \mathrm{CO}_{3}{ }^{2-} \rightarrow 2 \mathrm{NO}_{3}{ }^{1-}+{ }^{14} \mathrm{CO}_{2(\mathrm{~g})}+\mathrm{H}_{2} \mathrm{O} \\
& \mathrm{HNO}_{3}+{ }^{14} \mathrm{CN}^{-} \rightarrow \mathrm{H}^{14} \mathrm{CN}_{(\mathrm{g})}+\mathrm{NO}_{3}^{-}
\end{aligned}
$$

The off-gas stream from the dissolver was passed through an iodine-bed reactor column that vents to the vessel vent system. This column contains burl saddles coated with silver that removes volatile radioactive fission product iodine (evolved as $\mathrm{HI}$ ). If $\mathrm{H}^{14} \mathrm{CN}$ is present in the off-gas, the bed also removed it by forming insoluble $\mathrm{Ag}^{14} \mathrm{CN}$ during nitric acid dissolution of the irradiated fuel. When the column bed reached its loading capacity, the saddles containing $\mathrm{AgI}$ (and possibly $\mathrm{Ag}^{14} \mathrm{CN}$ ) were replaced. During early processing, the columns were treated with acid to remove silver containing species. The resulting solution was then transferred to the waste tanks (Tank 7F and Tank $13 \mathrm{H}$ ). If $\mathrm{Ag}^{14} \mathrm{CN}$ was a component in this waste, then it would be a component of the sludge waste in these receiving tanks.

\subsection{HM Process}

To enable recovery of the enriched uranium from extruded tubular fuel elements, the $\mathrm{H}$ Canyon process was changed from the Purex Process to the H-Modified (HM) Process in the early 1960's. In this process, a separate chemical decladding operation is not used. Instead, the U/Al alloy and Al cladding used to fabricate the fuel tubes are co-dissolved in $\sim 8 \mathrm{M}$ nitric acid.

Mercury(II), which is used as a catalyst to increase the rate of aluminum dissolution in nitric acid, reacts with $\mathrm{CN}^{-}$to form slightly soluble $\mathrm{Hg}(\mathrm{CN})_{2}$, which is very stable. Ionic dissociation of this compound is so slight that solutions containing $\mathrm{Hg}(\mathrm{CN})_{2}$ yield no mercury precipitate with potassium hydroxide or potassium iodide. (Ref. 9) The stability of this compound may prevent the evolution of HCN from the dissolver during nitric acid dissolution, if cyanide is present.

Variations of the basic HM process are used to recover other actinide products such as ${ }^{237} \mathrm{~Np}$ or ${ }^{233} \mathrm{U}$. Other modifications in the $\mathrm{H}$ Canyon enabled ion-exchange processing to recover products from special irradiations such as $\mathrm{Cm},{ }^{238} \mathrm{Pu}$ or Cf.

\subsubsection{Aluminum/Uranium Co-dissolution (HM)}

Nitric acid reacts with cyanide, carbide and carbonate species that may have formed from ${ }^{14} \mathrm{C}$ generated by $(n, p)$ reactions to evolve hydrogen cyanide and carbon dioxide as off-gas components from the dissolver, if any of these species are present in the $\mathrm{U}$ or Al. Reactions are shown in the following equations, assuming carbide and/or $\mathrm{Al}$ reduces nitrate to a mixture of nitrogen dioxide and ammonia (ammonia is assumed and would be retained as ammonium nitrate in the acid solution, although it likely would be subsequently oxidized to an oxide of nitrogen as dissolution proceeds):

$$
\begin{aligned}
& \mathrm{HNO}_{3}+{ }^{14} \mathrm{CN}^{-} \rightarrow \mathrm{H}^{14} \mathrm{CN}_{(\mathrm{g})}+\mathrm{NO}_{3}{ }^{1-} \\
& 22 \mathrm{HNO}_{3}+\mathrm{Al}_{4}\left({ }^{14} \mathrm{C}\right) \rightarrow 4 \mathrm{Al}\left(\mathrm{NO}_{3}\right)_{3}+8 \mathrm{NO}_{2}(\mathrm{~g})+{ }^{14} \mathrm{CO}_{2(\mathrm{~g})}+\mathrm{NH}_{4} \mathrm{NO}_{3}+9 \mathrm{H}_{2} \mathrm{O} \\
& 6 \mathrm{HNO}_{3}+\mathrm{U}^{14} \mathrm{C} \rightarrow \mathrm{UO}_{2}\left(\mathrm{NO}_{3}\right)_{2}+2 \mathrm{NO}_{2(\mathrm{~g})}+{ }^{14} \mathrm{CO}_{2}(\mathrm{~g})+\mathrm{NH}_{4} \mathrm{NO}_{3}+\mathrm{H}_{2} \mathrm{O} \\
& 2 \mathrm{HNO}_{3}+{ }^{14} \mathrm{CO}_{3}{ }^{2-} \rightarrow 2 \mathrm{NO}_{3}{ }^{1-}+{ }^{14} \mathrm{CO}_{2(\mathrm{~g})}+\mathrm{H}_{2} \mathrm{O}
\end{aligned}
$$


The subsequent permanganate strike used in the head-end treatment removes insoluble mercury compounds remaining in the solution, eventually becoming a component in the HLW sludge stored in $\mathrm{H}$ Area waste tanks. Any soluble cyanide that remained in the feed to solvent extraction was likely present as slightly soluble $\mathrm{Hg}(\mathrm{CN})_{2}$ and was rejected to the $1 \mathrm{AW}$ waste stream, which was then neutralized and transferred to an H-Area waste tank.

\subsection{Possible ${ }^{14} \mathrm{C}$ Sources Related to Reactor Operations}

Additional carbonate and cyanide may form during irradiation on the surfaces of the targets and in the moderator $\left(\mathrm{D}_{2} \mathrm{O}\right)$ from similar transformations of ${ }^{14} \mathrm{~N}$ and ${ }^{17} \mathrm{O}$ as those noted above. Principal ${ }^{14} \mathrm{~N}$ and ${ }^{17} \mathrm{O}$ precursors in moderator include:

- Nitric acid used to adjust the $\mathrm{pH}$, providing a source of soluble ${ }^{14} \mathrm{~N}$ as $\mathrm{NO}_{3}{ }^{-}$.

- $\mathrm{N}_{2}$ and $\mathrm{O}_{2}$ in the vapor space of a reactor vessel.

- $\mathrm{N}_{2}$ and $\mathrm{O}_{2}$ dissolved in the moderator from contact with air during circulation.

- Oxide in the $\mathrm{D}_{2} \mathrm{O}$ and on the exterior of metal surfaces (metal oxides) of the reactors that are exposed to moderator or high neutron flux.

These potential sources dominate the production of ${ }^{14} \mathrm{C}$ during irradiation cycles, far exceeding the quantities generated within the fuel and targets during irradiation. (Ref. 6) As noted above, the moderator is in intimate contact with the fuel and targets and at least a small fraction of the ${ }^{14} \mathrm{C}$ generated from the moderator is deposited in the metal matrix of the fuels and targets during irradiation.

Any bicarbonate and cyanide that was formed and dissolved in the moderator was either removed by ionexchange or evolved from the reactor stacks. The moderator is not sent to Separations for processing or to the waste tanks for disposal and it does not contribute significantly to the ${ }^{14} \mathrm{C}$ inventory in HLW stored at the SRS. In an estimate of ${ }^{14} \mathrm{C}$ generated during reactor operations, the quantity generated within the fuels was considered insignificant compared to the quantity generated in the moderator, based on measurements of moderator and stack releases from both the Reactor areas and the Separations areas at the SRS. (Ref. 6)

\subsubsection{Possible ${ }^{14} \mathrm{C}$ Sources from the Receiving Basin for Offsite Fuels (RBOF)}

Spent resins from reactor operations were regenerated in RBOF, but the bulk of any $\mathrm{CO}_{2}$ formed during regeneration was released from the RBOF stack, when the combined acid and basic streams were combined with other acid streams (acidic dichromate) prior to neutralization and transfer to Tank 23H. Some may have been sent to Tank $23 \mathrm{H}$ from RBOF as $\mathrm{Na}_{2} \mathrm{CO}_{3}$, if insufficient acid was present to yield a $\mathrm{pH}<3$. This potential source was passed directly through the CRC on Tank 24 and released to the HArea seepage basin through 1988 when the basin was closed. After the basins were closed, CRC operations were also terminated. Soluble waste from RBOF that was sent to Tank $23 \mathrm{H}$ was redirected to one of the H-Area evaporator systems.

Presently, spent resins from the moderator systems are stored in drums in the reactor areas. These resins are known to contain a significant quantity of ${ }^{14} \mathrm{C}$. The actual chemical form of the ${ }^{14} \mathrm{C}$ remaining in these resins is assumed to be carbonate, although cyanide cannot be precluded, since it may have formed during irradiation and removed by the resins, but not effectively purged during regeneration. Appropriate analysis of spent resins may provide information on the possible formation of cyanide during irradiation. 


\subsubsection{Possible ${ }^{14} \mathrm{C}$ Sources Heat Exchanger Cleaning}

Spent oxalic acid solutions from the Reactor Areas that were sent to F Tank Farm likely contained some ${ }^{14} \mathrm{C}$ as dissolved $\mathrm{CO}_{2}$ (or bicarbonate) and/or cyanide that was generated during descaling of the heat exchangers. After neutralizing the spent oxalic acid with $\mathrm{KOH}$ from these activities, the waste was sent to Tank 7F. Cleaning of heat exchangers was stopped in the early 1980's.

\subsubsection{Possible ${ }^{14} \mathrm{C}$ Sources from the Reactor Sand Filter Failure}

A slurry of sand and coal filter media from a failed sand filter located in a reactor area was transferred to Tank 7F in the 1970's. This filter media likely contained ${ }^{14} \mathrm{C}$ as $\mathrm{CO}_{2}$ and/or $\mathrm{HCN}$ adsorbed on the solid surfaces of the media.

\subsection{Chemicals Containing C with Natural Isotopic Distribution}

Principal chemicals containing $\mathrm{C}$ with natural isotopic distribution that may be sent to a waste tank include:

- Lubricants containing stearic acid and other organic compounds that were used during the extrusion process of fuel tubes and cladding. Although the fuel and targets were cleaned (degreased with fluorochlorocarbon compounds) before sending them to the reactors, small quantities of these materials are likely occluded within the bulk aluminum metal during extrusion into tubes and cladding.

- Carbon-based compounds such as organic solvents, tributyl phosphate (TBP), dibutyl phosphate (from TBP decomposition), sodium carbonate (used in solvent washing) and oxalic acid or oxalates used during processing of fuels and targets, to decontaminate equipment (299-H) and to clean waste tanks (Tank 16).

- Waste from digested ion exchange resins from various ion exchange processes used in several processes.

- Direct disposal of ion exchange resins to a waste tank.

- Tetraphenylborate and its decomposition products (limited to Tank 48H, Tank 49H and Tank 50H).

- Waste from various laboratory analyses.

- Sorption of carbon dioxide from air by caustic solutions stored in the waste tanks.

These "natural carbon" sources in the stored waste dilute the "enriched ${ }^{14} \mathrm{C}$ ” generated from processing irradiated fuels.

\subsection{Chemistry in the SRAT, SME, SMECT and MFT}

\subsection{Aqueous Waste Processing of Carbonate}

Carbonate dominates as the principal carbon containing species stored in the SRS waste tanks, with soluble sodium carbonate being the major form. Most of the soluble carbonate will eventually be processed for disposal as a component of Saltstone. The principal sources of ${ }^{14} \mathrm{C}$ in feed to the DWPF are insoluble carbonates that are components of the sludge solids (e.g., $\mathrm{CaCO}_{3}, \mathrm{SrCO}_{3}$ and $\mathrm{BaCO}_{3}$ ) and residual sodium carbonate dissolved in the aqueous solution from sludge processing.

\subsubsection{SRAT/SMECT}

During SRAT operation, nitric acid and formic acid are added to the SRAT to assure an acidic $\mathrm{pH}(\sim 5)$ at the end of the SRAT cycle. SMECT condensate, which supplies the ammonia scrubbers, is also 
maintained at a $\mathrm{pH}$ of $\sim 2$ to maintain the scrubbing efficiency for ammonia generated during SRAT reactions. During the reflux cycle of the SRAT under acidic conditions ( $\mathrm{pH} \leq 5, \mathrm{~T} \sim 100^{\circ} \mathrm{C}$ ), $\mathrm{CO}_{2}$ formed in the SRAT through acid/base reactions between formic acid and carbonates in the waste would be effectively stripped from the slurry:

$$
\begin{array}{ll}
\mathrm{M}_{2} \mathrm{CO}_{3}+2 \mathrm{HCOOH} \rightarrow 2 \mathrm{MCOOH}+\mathrm{CO}_{2(\mathrm{~g})}+\mathrm{H}_{2} \mathrm{O} & \left(\mathrm{M}=\mathrm{Na}^{1+}, \mathrm{K}^{1+}, \mathrm{Cs}^{1+}, \mathrm{Rb}^{1+}, \mathrm{NH}_{4}{ }^{1+}\right) \\
\mathrm{MCO}_{3}+2 \mathrm{HCOOH} \rightarrow \mathrm{M}(\mathrm{COOH})_{2}+\mathrm{CO}_{2(\mathrm{~g})}+\mathrm{H}_{2} \mathrm{O} & \left(\mathrm{M}=\mathrm{Mg}^{2+}, \mathrm{Ca}^{2+}, \mathrm{Sr}^{2+}, \mathrm{Ba}^{2+}, \mathrm{Ni}^{2+}, \mathrm{Pb}^{2+}\right)
\end{array}
$$

Redox reactions between metals in higher oxidation states and formic acid generate carbon dioxide in the slurry. As the redox reactions proceed, the $\mathrm{CO}_{2}$ (with natural abundance of ${ }^{14} \mathrm{C}$ ) simultaneously purges the solution and dilutes the concentration of ${ }^{14} \mathrm{C}$ in $\mathrm{CO}_{2}$ evolved from the SRAT:

$$
\begin{aligned}
& \mathrm{HgO}+\mathrm{HCOOH} \rightarrow \mathrm{Hg}(\mathrm{l}) \\
& \mathrm{MnO}_{2}+3 \mathrm{CCOOH} \rightarrow \mathrm{Mn}(\mathrm{COOH})_{2}+\mathrm{CO}_{2(\mathrm{~g})}+2 \mathrm{H}_{2} \mathrm{O}
\end{aligned}
$$

SRAT, SME and SMECT operations effectively eliminate carbonates "enriched" with ${ }^{14} \mathrm{C}$ as a component of the melter feed by converting the carbonates to soluble formate (with natural abundance of ${ }^{14} \mathrm{C}$ ), bicarbonate (with natural abundance of ${ }^{14} \mathrm{C}$ ) or nitrate salts. $\mathrm{CO}_{2(\mathrm{~g})}$ (with natural abundance of ${ }^{14} \mathrm{C}$ ) in air used to purge the SRAT further dilutes the concentration of ${ }^{14} \mathrm{C}$ in residual "enriched" $\mathrm{CO}_{2(\mathrm{~g})}$ or bicarbonate that remains in the SRAT solution, especially during the extended reflux cycle that strips mercury from the SRAT. Furthermore, the air purge of the SRAT and SMECT provides a sweep of the vapor space in these vessels, which would reduce the concentration of "enriched" $\mathrm{CO}_{2}$ (g) by diverting it to the Process Vessel Vent System. At the end of the SRAT process cycle, the isotopic distribution of $\mathrm{C}$ in any $\mathrm{CO}_{2(\mathrm{~g})}, \mathrm{HCO}_{3}{ }^{1-}$ or $\mathrm{COOH}^{1-}$ would not differ significantly from naturally occurring carbon.

\subsubsection{SME/MFT}

Additional formic acid is added with the frit slurry to assure the $\mathrm{pH}$ of the sludge/frit slurry is acidic at the end of SME cycle to facilitate transfer to the MFT and subsequent feeding of the melter. These vessels are also purged with air. The net effect of SME/MFT operations is to further dilute any residual carbon compounds that are "enriched" in ${ }^{14} \mathrm{C}$ with compounds (formate, $\mathrm{CO}_{2}$ (g) ) containing natural abundance of ${ }^{14} \mathrm{C}$.

\subsection{Waste Processing Chemistry of Cyanide}

Cyanide salts have not been used in any of the Separations processes at the SRS. [Cyanide complexes of iron were added in some tanks at Hanford to precipitate cesium.] Compounds containing cyanide have not been identified as components in the HLW waste stored at the SRS because no one has ever analyzed waste with the intent of finding cyanide. Although it has not been identified as a component of the waste, its known chemistry is considered here to determine if cyanide would survive as a component of the glass waste forms.

\subsubsection{Possible Forms of Cyanide}

In reviewing the fuel fabrication and reactor operations, transmutation of $\mathrm{N}_{2}$ in air during irradiation cycles followed by chemical interaction with additional $\mathrm{N}_{2}$ would be the primary pathway to obtain cyanide containing ${ }^{14} \mathrm{C}$. Cyanide from irradiation of air in the reactor would be released from the reactor stacks, dissolved in the moderator, deposit on steel surfaces within the reactor or be removed by the resins used to remove ionic species from the moderator. 
The quantity of air trapped within sealed cans during canning and extrusion operations would be extremely small. Likewise the quantity of nitrogen dissolved in the metals used to fabricate fuel and targets would be low. If cyanide salts of $\mathrm{Al}^{+3}$ formed on the exterior surfaces of the targets and fuel tubes through reaction with cyanide dissolved in the moderator, they would readily hydrolyze to yield aluminum hydroxide and HCN or soluble cyanide salts. Any HCN or soluble cyanide salts dissolved in moderator would accumulate on the resins used to remove ionic species during normal reactor operations. Transmutation of dissolved nitrogen within the metal matrices is the only potential source of cyanide within the targets and fuels. Theoretically, sodium cyanide could have survived and been transferred to the waste tanks as $\mathrm{NaCN}$ in coating waste from Purex processing in both $\mathrm{F}$ and $\mathrm{H}$ Areas, although oxidation to carbonate is likely during caustic or acid dissolution of the cladding, fuels and targets in the presence of nitrate.

Waste generated from resin regeneration is another potential source for sodium cyanide in the waste. The resins used in the reactor areas were regenerated in RBOF. Liquid waste from these operations was sent to the Tank Farms as part of the RBOF waste sent to Tank 23H. Most of this waste was transferred directly to the H-Area CRC from Tank 23H and then released to the H-Area Seepage Basin. In the late 1980's, after the basin was closed, soluble aqueous waste from Tank 23 was periodically transferred to the Tank Farm evaporator systems to reduce the storage volume.

Because mercury is ubiquitous in the HLW stored in H-Area tanks, soluble cyanide introduced from any source would react to form $\mathrm{Hg}(\mathrm{CN})_{2}$. $\mathrm{Hg}(\mathrm{CN})_{2}$ could be a chemical species in sludge and salt solution that contains cyanide. Subsequent blending and washing of sludges from F-Area and H-Area could lead to the formation of additional $\mathrm{Hg}(\mathrm{CN})_{2}$ from traces of $\mathrm{NaCN}$, if it is present in the salt solutions accompanying the sludges transferred from F Area..

\subsubsection{Fate of Cyanide in DWPF Melter Feed Preparation}

If $\mathrm{Hg}(\mathrm{CN})_{2}$ can survive the dissolution in strong acid used in the HM Process, then it would also survive less stringent conditions used to prepare melter feed in the SRAT and SME. If it does not survive the dissolution conditions, then $\mathrm{Hg}(\mathrm{CN})_{2}$ can only reach the DWPF from other sources, such as a component of RBOF waste. To remain in the melter feed, $\mathrm{Hg}(\mathrm{CN})_{2}$ must survive the formic acid treatment that reduces mercury compounds to mercury metal. Because waste has not been checked for the presence of cyanide in any form, $\mathrm{Hg}(\mathrm{CN})_{2}$ is assumed to be a component in the melter feed, and its reactions in the melter are considered below.

\subsection{Carbon Chemistry in the Melter}

Carbon is present in several different forms in the waste tanks:

- Carbonate salts from caustic dissolution of aluminum (Purex);

- Carbonate salts formed by absorption of $\mathrm{CO}_{2}$ (g) from air used to purge waste tanks;

- Oxalate salts from processes and equipment decontamination in Separations areas, reactor areas and the Tank Farms;

- Formate salts from melter feed preparation in S Area and formic acid denitration tests in H Area;

- Elemental carbon (coal) that was transferred to Tank 7F when a sand filter in a reactor area failed;

- Various soluble and insoluble organic compounds (e.g., organic resins, degraded extractants, TPB). 
Carbonate dominates as the primary chemical form of carbon in stored waste. The total carbonate inventory will continue to increase as $\mathrm{CO}_{2(\mathrm{~g})}$ in air purges is absorbed by the caustic waste to form sodium carbonate. Conversely, the isotopic content of ${ }^{14} \mathrm{C}$ in carbon containing species within the salt waste decreases over time because of $\mathrm{CO}_{2 \text { (g) }}$ absorption and reaction with caustic. As discussed above, processes used to prepare feed for the melter effectively remove carbonate species from the melter feed, thus eliminating the primary potential source of carbon enriched with ${ }^{14} \mathrm{C}$ from the slurry that is fed to the melter. The chemistry of remaining carbon compounds are discussed below.

Formate and oxalate salts have been sent to the waste tanks from Separations, Reactors and other miscellaneous operations, including DWPF recycled waste. Although cyanide has never been identified as a waste component, it may be present in low concentrations, probably as $\mathrm{Hg}(\mathrm{CN})_{2}$. If cyanide is present, the most likely source is RBOF waste from resin regeneration (added as a sodium salt to Tank 23H), and it would be enriched in ${ }^{14} \mathrm{C}$. Interaction with $\mathrm{Hg}$ contained in the waste stored in the H-Area Tank Farm is assumed to have formed $\mathrm{Hg}(\mathrm{CN})_{2}$. The expected chemistry in the melter for these various carbon compounds are considered below.

\subsection{Formate and Oxalate Salts}

Based on known chemistry and physical properties, soluble and insoluble formate salts and oxalate salts will either react with oxidizing species in the cold cap and the surface of the melt pool or simply decompose. Sodium formate is the principal formate salt in the melter feed. It is used to describe the various reactions of formate salts that likely occur in the cold cap.

Formate salts react with insoluble metal oxides (e.g., $\mathrm{Fe}_{2} \mathrm{O}_{3}$ ) to yield metal oxides in lower oxidation states, or with $\mathrm{NaNO}_{3}$ to yield $\mathrm{NaHCO}_{3}$ and $\mathrm{NaNO}_{2}$. These two compounds subsequently decompose in the cold cap (at $270^{\circ} \mathrm{C}$ and $320^{\circ} \mathrm{C}$, respectively, for the pure compounds) to yield $\mathrm{Na}_{2} \mathrm{O}$, oxides of nitrogen, $\mathrm{CO}_{2}$ and water:

$$
\begin{aligned}
& 2 \mathrm{NaCOOH}+2 \mathrm{Fe}_{2} \mathrm{O}_{3} \rightarrow 4 \mathrm{FeO}+2 \mathrm{CO}_{2(\mathrm{~g})}+\mathrm{Na}_{2} \mathrm{O}+\mathrm{H}_{2} \mathrm{O}(\mathrm{g}) \\
& 2 \mathrm{NaCOOH}+2 \mathrm{NaNO}_{3} \rightarrow 2 \mathrm{NaNO}_{2}+2 \mathrm{NaHCO}_{3} \rightarrow 2 \mathrm{Na}_{2} \mathrm{O}+\mathrm{NO}_{(\mathrm{g})}+\mathrm{NO}_{2(\mathrm{~g})}+2 \mathrm{CO}_{2(\mathrm{~g})}+\mathrm{H}_{2} \mathrm{O}(\mathrm{g})
\end{aligned}
$$

If all of the formate salts are not consumed in other reactions, they thermally decompose to oxalate salts and hydrogen. For example, sodium formate decomposes at about $200^{\circ} \mathrm{C}$ (Ref. 11):

$$
2 \mathrm{NaCOOH} \rightarrow \mathrm{Na}_{2} \mathrm{C}_{2} \mathrm{O}_{4}+\mathrm{H}_{2} \text { (g) }
$$

Sodium oxalate, which forms when sodium formate thermally decomposes, is also a component of the melter feed. Sodium oxalate also reacts with insoluble metal oxides (e.g., $\mathrm{Fe}_{2} \mathrm{O}_{3}$ ) in the cold cap and on the melt pool surface to yield metal oxides in lower oxidation states, or with $\mathrm{NaNO}_{3}$ to yield $\mathrm{Na}_{2} \mathrm{O}$, oxides of nitrogen and $\mathrm{CO}_{2}$ :

$$
\begin{aligned}
& \mathrm{Na}_{2} \mathrm{C}_{2} \mathrm{O}_{4}+\mathrm{Fe}_{2} \mathrm{O}_{3} \rightarrow 2 \mathrm{FeO}+\mathrm{Na}_{2} \mathrm{O}+2 \mathrm{CO}_{2}(\mathrm{~g}) \\
& 2 \mathrm{Na}_{2} \mathrm{C}_{2} \mathrm{O}_{4}+2 \mathrm{NaNO}_{3} \rightarrow 3 \mathrm{Na}_{2} \mathrm{O}+\mathrm{NO}_{(\mathrm{g})}+\mathrm{NO}_{2(\mathrm{~g})}+4 \mathrm{CO}_{2(\mathrm{~g})}
\end{aligned}
$$

In the absence of an oxygen source, oxalate salts decompose in the range of $400-550^{\circ} \mathrm{C}$, yielding a metal carbonate and $\mathrm{CO}$ :

$$
\mathrm{Na}_{2} \mathrm{C}_{2} \mathrm{O}_{4} \rightarrow \mathrm{Na}_{2} \mathrm{CO}_{3}+\mathrm{CO}_{(\mathrm{g})}
$$


from treatments that convert carbonate salts (potentially enriched in ${ }^{14} \mathrm{C}$ ) to formate (natural abundance). The continuous air purges (natural abundance) of the various tanks shifts the isotopic ratio of any $\mathrm{CO}_{2}$ remaining after SRAT and SME operations are complete.

\subsection{Mercuric Cyanide}

Mercuric cyanide, $\mathrm{Hg}(\mathrm{CN})_{2}$, thermally decomposes at $\sim 320^{\circ} \mathrm{C}$ to yield $\mathrm{Hg}$ and cyanogen, $(\mathrm{CN})_{2}$. (Ref. 9), and would be evolved from the cold cap in the melter:

$$
\mathrm{Hg}(\mathrm{CN})_{2} \rightarrow \mathrm{Hg}_{(\mathrm{g})}+(\mathrm{CN})_{2(\mathrm{~g})}
$$

Cyanogen readily burns in oxygen to yield oxides of nitrogen and oxides of carbon, and would be destroyed in the plenum space of the melter. In fact, a stoichiometric mixture of $\mathrm{O}_{2}$ and (CN) burns to produce one of the hottest flames $\left(\sim 5050^{\circ} \mathrm{K}\right)$ known from a chemical reaction (Ref. 10):

$$
(\mathrm{CN})_{2(\mathrm{~g})}+4 \mathrm{O}_{2(\mathrm{~g})} \rightarrow 2 \mathrm{CO}_{2}+2 \mathrm{NO}_{2(\mathrm{~g})}
$$

\subsection{Carbonate and Bicarbonate Salts}

If carbonate or bicarbonate salts reach the melter, the combination of heat, steam and acid in the feed will smoothly decompose any surviving carbonates or bicarbonates to metal oxides and carbon dioxide. However, dry carbonates formed by thermal decomposition of alkali oxalates will likely persist in the cold cap until they reach the surface of the melt pool. For example, sodium carbonate does not decompose until it reaches a temperature of $800-900^{\circ} \mathrm{C}$, while sodium bicarbonate decomposes at $270{ }^{\circ} \mathrm{C}$ :

$$
\begin{aligned}
& \mathrm{Na}_{2} \mathrm{CO}_{3} \rightarrow \mathrm{Na}_{2} \mathrm{O}+\mathrm{CO}_{2}(\mathrm{~g}) \\
& 2 \mathrm{NaHCO}_{3} \rightarrow \mathrm{Na}_{2} \mathrm{O}+2 \mathrm{CO}_{2(\mathrm{~g})}+\mathrm{H}_{2} \mathrm{O}_{(\mathrm{g})}
\end{aligned}
$$

\subsection{Elemental Carbon}

Elemental carbon is relatively inert at ambient temperature and is not affected significantly by aqueous solutions of dilute acids or bases. Concentrated nitric acid will oxidize carbon (ref. 11):

$$
\mathrm{C}+4 \mathrm{HNO}_{3} \rightarrow \mathrm{CO}_{2(\mathrm{~g})}+4 \mathrm{NO}_{2(\mathrm{~g})}+2 \mathrm{H}_{2} \mathrm{O}
$$

When carbon is heated to higher temperatures $\left(>200^{\circ} \mathrm{C}\right)$, it can react with a number of substances, including steam. It combines with oxygen with the liberation of considerable heat to give a mixture of carbon monoxide and carbon dioxide, with the relative yields of these products being dependent upon the temperature and the proportions of the reactants. Carbon monoxide is formed almost quantitatively by the combustion of carbon in an insufficient supply of air at $1000^{\circ} \mathrm{C}$; at temperatures in the neighborhood of $500^{\circ} \mathrm{C}$, carbon dioxide is practically the sole product, even when carbon is in excess. (Ref. 10)

Elemental $\mathrm{C}$ would react in the cold cap with oxygen to generate $\mathrm{CO}_{2}$ as the feed slurry is introduced into the DWPF melter:

$$
\mathrm{C}+\mathrm{O}_{2(\mathrm{~g})} \rightarrow \mathrm{CO}_{2(\mathrm{~g})}
$$




\subsection{References}

1. William R. McDonell, George R. Caskey and Carl L. Angerman, "High Performance UraniumMetal Fuels for Savannah River Reactors,” WSRC-MS-2000-00061, pp. 24-29.

2. Phillip H. Permar, "Development of Coextruded Fuel and Target Tubes for the Savannah River Plant Reactors,” ibid., pp. 19-21.

3. James M. Morrison, “Reactor Program for increased Production Capacity,” ibid. pp. 91-98.

4. James M. Boswell, “Reactor Production Diversity,” ibid. pp. 99-107.

5. Harold Peacock, Personal Communication, November 2004.

[Harold Peacock has worked many years at the SRS in 300-M Area and SRNL, primarily in the area of production of aluminum-clad fuels and targets used in the SRS production reactors. He confirmed that nitric acid was used to etch U slugs before canning. It was also used to etch the nickel plating layer before canning, when nickel plating was adopted to provide a thermal bond between U and Al. Except for a four-year period between 1969 to 1973 when blasting with walnut shells were used, nitric acid was used to remove die lubricants from the cans and lids prior to welding from startup in 1955 until 1969 and from 1973 to 1976. A mechanical grinder was adopted to clean the area at the seam between the can and the lids in 1976. Etching of U slugs and the nickel-plating layer was used continuously as part of the 300-M canning operations.]

6. D. W. Hays and K. W. MacMurdo, “Carbon-14 Production by the Nuclear Industry,” Health Physics 32, 215 (April 1977).

7. J. B. Starks, “The Purex Process,” DPSPU 77-11-1, E. I. du Pont de Nemours \& Company, Inc., January 1977.

8. M. L. Hyder, W. C. Perkins, M. C. Thompson, G. A. Burney, E. R. Russell, H. P. Holcomb and L. F. Landon, "Processing of Irradiated Enriched Uranium Fuels at the Savannah River Plant," DP-1500, E. I. du Pont de Nemours \& Company, Inc., April 1979.

9. Jacob Kleinberg, William J. Argersinger, Jr. and Ernest Griswold, Inorganic Chemistry, D. C. Heath and Company (Boston, 1960)

10. F. Albert Cotton and Geoffrey Wilkinson, Advanced Inorganic Chemistry (2 ${ }^{\text {nd }}$ Edition), Interscience Publishers (New York, 1966)

11. W. Norton Jones, General Chemistry, The Blakiston Company, Inc. (New York, 1954).

12. Handbook of Chemistry and Physics, $22^{\text {nd }}$ Edition, Chemical Rubber Publishing Co., (Cleveland, Ohio, 1937), page 942. 